NBER WORKING PAPER SERIES

\title{
RE-EXAMINING THE MIDDLE-INCOME TRAP HYPOTHESIS (MITH): WHAT TO REJECT AND WHAT TO REVIVE?
}

\author{
Xuehui Han \\ Shang-Jin Wei \\ Working Paper 23126 \\ http://www.nber.org/papers/w23126 \\ NATIONAL BUREAU OF ECONOMIC RESEARCH \\ 1050 Massachusetts Avenue \\ Cambridge, MA 02138 \\ February 2017
}

The views expressed in this paper are those of the authors and do not necessarily reflect the views and polices of the Asian Development Bank, its Board of Governors, the governments they represent, or the National Bureau of Economic Research. The authors are grateful for comments from Francesco Caselli, David Cook, Andreas Madestam, Uwe Sunde, Lei Lei Song, and participants of an ADB seminar and the Asian Bureau of Finance and Economic Research 2015 annual conference, and the excellent research assistance by Orlee P. Velarde, Lea R. Sumulong, and Nedelyn C. Magtibay-Ramos. The authors are responsible for any remaining errors in the paper.

At least one co-author has disclosed a financial relationship of potential relevance for this research. Further information is available online at http://www.nber.org/papers/w23126.ack

NBER working papers are circulated for discussion and comment purposes. They have not been peer-reviewed or been subject to the review by the NBER Board of Directors that accompanies official NBER publications.

(C) 2017 by Xuehui Han and Shang-Jin Wei. All rights reserved. Short sections of text, not to exceed two paragraphs, may be quoted without explicit permission provided that full credit, including $(\odot$ notice, is given to the source. 
Re-examining the Middle-Income Trap Hypothesis (MITH): What to Reject and What to Revive? Xuehui Han and Shang-Jin Wei

NBER Working Paper No. 23126

February 2017

JEL No. O1,O4

\begin{abstract}
Do middle-income countries face difficult challenges producing consistent growth? Using transition matrix analysis, we can easily reject any unconditional notion of a "middle-income trap" in the data. However, countries have different fundamentals and policies. Using a nonparametric classification technique, we search for variables that separate fast- and slowgrowing countries. For middle-income countries, a relatively large working age population, sex ratio imbalance, macroeconomic stability, and financial development appear to be the key discriminatory variables. We do the same exercise for low-income countries. This framework yields conditions under which countries in the low- and middle-income ranges move forward or backward, or are trapped.
\end{abstract}

Xuehui Han

Asian Development Bank

6 ADB Avenue

Mandaluyong City

Manila, Philippines 1550

xuehuihan@adb.org

Shang-Jin Wei

Graduate School of Business

Columbia University

Uris Hall 619

3022 Broadway

New York, NY 10027-6902

and NBER

shangjin.wei@columbia.edu

A online appendix is available at http://www.nber.org/data-appendix/w23126 


\section{Introduction}

Is the task of attaining the living standard of today's OECD countries by middle-income countries much harder than catching up with today's middle-income countries by low-income countries? Perhaps as important, within any given income group, why do some countries grow faster than others? Are there clear and quantifiable indicators that will separate fast-growing economies from slow-growing ones? These are the questions that this paper will investigate.

By usage count, the concept of the middle-income trap is a run-away success. Even though the term was only invented a decade ago (by Gill and Kharas, 2007), a Google Scholar search returns about 3,680 articles, and a regular Google search (which also includes journalistic accounts and casual blogs) returns more than 175,000 results. ${ }^{1}$ Is this a bubble, or is it a conceptual breakthrough?

Gill and Kharas (2007) invented the term in a World Bank report, An East Asian Renaissance. The term appeared once on page 17 in a section title ("avoiding the middle-income trap") of the executive summary of the report. The relatively short section does not contain a precise definition of the term. It does assert that middle-income countries in Latin America and Africa fail to escape the trap, and middle-income countries in East Asia face an uphill battle "in the absence of economies of scale." The rest of the report does not use the term and therefore does not define it.

The second and third usages of the term occurred in Woo (2009) and Ohno (2009), respectively. Woo (2009) asserts that Malaysia is caught in a middle-income trap, whereas Ohno (2009) asserts that Viet Nam is in danger of falling into a middle-income trap and cannot attain a high-income status. While neither paper gives a precise definition, both appear to use the term to describe a situation in which the country in question used to grow very fast when it was poor but exhibits a precipitous drop in the growth rate once it becomes a middle-income country. The middle-income trap hypothesis (MITH) in these cases therefore appears to postulate that it is substantially more challenging for middle-income countries to move up the income ladder to attain a high-income country's living standard than for low-income countries to move up the ladder and obtain a middle-income country's living standard.

The popularity of the term then grows exponentially. In Gill and Kharas' review article (2015), they described the rise of the usage in the following way:

"To our surprise, the phrase "middle-income trap" immediately became popular among policy makers and development specialists. In East Asia, the Great Recession of 2008 rocked the confidence of economic policy makers and triggered a big debate on what to do next. By mid-2009, Malaysian policy makers, including Prime Minister Najib, had started to use the phrase in speeches and even launched a National Economic Advisory Council to elaborate a plan on how to escape the trap. In Viet Nam, the Deputy Prime Minister Nguyen Thien Nhan had used the concept in 2009, also influenced by Kenichi Ohno (2009) who was writing about his own version of the trap, referring to the lack of industrial

\footnotetext{
${ }^{1}$ Both searches were conducted on March 15, 2016.
} 
upgrading in the economy. In the People's Republic of China (PRC), from 2010 onwards, officials in charge of the preparation of the 12th Five Year Plan 2011-2016, including Liu $\mathrm{He}$, started to actively debate whether the PRC was becoming vulnerable to the middle-income trap.

As government leaders repeatedly referred to the term, first academics and then the mainstream media started to adopt the term. By mid-2011, there were enough newspaper headlines per month using the term "middle-income trap" to register in Google trends. Following the launch of the World Bank's China 2030 report in February 2012, which also referred to the middle-income trap, the level of media interest increased further. Since 2012 , there has been a steady stream of monthly headlines using the term.

Academics also became interested in the subject. By May 2015, a search of Google Scholar returned over 3,000 articles including the term "middle-income trap" and close to 300 articles with the term in the title. However, these papers do not use a common definition. Instead, the term has been loosely used to describe situations where a growth slow-down results from bad policies in middle-income countries that prove difficult to change in the short-run (hence, "trap")..."

The acceptance of the term in the research community is somewhat slower. Agénor, Canuto, and Jelenic (2012)), Eichengreen et al. (2012) in particular conclude that growth tends to slow down significantly when a country's income reaches around $\$ 15,000$ to $\$ 16,000$. As an update, Eichengreen et al. (2013) revised the conclusion to a significant slowdown in growth near two modes of $\$ 10,000-\$ 11,000$ and $\$ 15,000-\$ 16,000$ in 2005 purchasing power parity (PPP) terms. It is noteworthy that the researchers used the absolute levels of income (PPP dollars) to describe income buckets for the country and the associated challenges of growth. In fact, for many policy makers and journalists, when they invoke the term, they tend to express the concern - albeit sometimes implicitly - that most middle-income countries may never attain the living standards of today's United States. For example, Ohno (2009) worried that Viet Nam cannot reach high-income status as "the country has reached the point where growth towards higher income cannot be secured unless policy making is renovated significantly to activate the country's full potential." In our analysis, we will start with an exercise in which countries are grouped into different income buckets based on their income levels in PPP dollar terms.

There are also authors who chose to look at relative incomes - income of a country relative to that of the United States (US). For example, Robertson and Ye (2013) concludes that a middle-income country's per capita income relative to the reference country tends to lie within a band. Aiyar et al. (2013) reported that a typical country in the middle-income group has a higher frequency of negative deviations from the growth path compared with countries in the other two groups. In our exercise, we will also look at patterns of growth transition for countries in different relative income buckets.

While the phrase "middle income trap" was invented only in 2007, there has been an earlier literature on growth non-convergence (Quah, 1996a and1996b, and Kremer et al., 2001), where it was found that certain countries do not belong to a convergence club. The current MITH adds one 
more element to the previous non-convergence result by asserting that the challenge of further growth faced by middle income countries is greater than that by low income countries.

In the first part of the paper, we will examine whether countries that have reached a middle income status have a low probability of ever crossing the threshold to attain a high income living standard in both absolute and relative terms, and whether such countries also face a greater difficulty of growing further than countries in the low income group. We use a transition matrix to document the transition speed from low-income to middle-income group and from middle-income to high-income group, based on both decade average transition from 1960 to 2010 and 50 years average transition from 1850 to 2000 . We found no slowing down of middle-income countries moving up to high-income compared to the speed of the low-income countries moving up to middle-income. On the contrary, we found a higher growth rate (higher probability of moving up) for middle-income countries.

We also reject any notion of an unconditional middle-income trap. That is, a middle-income country that grows at the average or median rate of the middle-income group will clearly and surely become a high-income country, reaching and surpassing the living standard in today's US or France. In other words, in the data, a typical middle-income country is not expected to be stuck or trapped in middle-income status. The same thing can be said about a typical low-income country because the mean or the median growth rate is clearly positive. The only unconditional trap in the data is a "high-income trap." That is, because the median or the mean growth rate of high-income countries is also positive, once a country enters the high-income club, it is expected to stay there forever if it is to follow the mean or median growth rate of that group.

If we look at relative incomes (say, to that of the United States), however, the picture is different. We will document that, in the steady state, there is a distribution of relative incomes: some countries will be income leaders, other countries will have lower relative incomes, and there is no absolute convergence. Because the income level of the income leaders (say, the US) is a moving target, this pattern does not mean that a typical middle-income country cannot attain the living standard of today's high-income countries. A country whose income is forever only $50 \%$ of the US income can nevertheless grow very rich (as long as the US keeps growing as it has always been doing in the past). If citizens of a middle-income country compare their living standards with that of a leading country, some of them may feel "trapped" as they cannot get closer. However, the meaning of "trap" in this context is different from the one when the term "middle income trap" was invented. Even for countries whose income does not catch up with the United States, people can become very rich nonetheless. Moreover, we will document that the growth challenge facing the middle-income countries is no greater than that facing the low-income countries. In other words, countries in every income group face some growth challenges; there is no compelling reason to single out a particular income group.

We are not the first ones to discover these patterns in the literature. For example, Im and Rosenblatt (2013) employed transition matrices in the Maddison database over 1950-2008, and found no support for the notion of a middle-income trap in either absolute or relative terms. Felipe et al. (2014): because only a small number of former middle-income economies (Korea, Taiwan, Hong Kong, and Singapore) have become high income economies relatively quickly, 
which were outliers from a historic perspective, the rest of the middle-income economies appear weak in their growth performance. Using the transition matrix technique too, Bulman et al. (2014) documented the evidence against the existence of a middle-income trap. After examining the growth rate of countries across different income levels, they did not find stagnation at any particular income level.

Of course, countries in a given income group differ in their fundamentals and policy choices; so would their growth performances. To understand the roles of these fundamentals and policies, in the second part of the paper, we introduce a non-parametric classification technique (conditional inference regression tree) and examine which proposed determinants are most relevant in separating fast- and slow-growing economies, and how these separating variables may differ across income groups.

Relative to the more standard linear regressions in the existing empirical literature on economic growth, a key advantage of our non-parametric methodology is that it permits interactions among potential determinants in a very flexible way. A number of theoretical models predict interactive effects among variables (or other forms of non-linearity). For example, in Benhabib and Spiegel (2005), the growth of total factor productivity (TFP) is a non-linear function of human capital and the distance of that country's TFP from that of the leader country. In models by Galor and Zeira (1993) and Quah (1996b), a country's TFP growth depends on the skill level of its labor force and the ease of cross-border capital flows, respectively. In these settings, the interactions of a country's initial income level with either skill level of the labor force or international capital flows matter as well.

If one has a strong prior about the precise forms of interactions and with a precise list of variables that may interact, one can embed the relevant interaction terms into a linear regression specification (by simply defining a particular form of interaction as a new regressor). However, that requires a very narrow reading of theories of growth determinants and a very strong belief that interactions not modeled in existing theories do not exist in the real world. We prefer a more inclusive approach and do not exclude interactive effects among variables ex ante. The regression tree technique is well suited for this purpose. In particular, if certain factors become drivers of growth, or change the intensity of their effects on growth, conditional on certain other factors reaching certain levels, our approach will reveal that.

Based on our empirical results, we classify all middle-income countries into three groups: progressive, near-stagnant, and regressive countries. In other words, we can now identify conditions under which middle-income countries can be trapped in their income status or even move backward. As a preview of the key results, we will report that demographics (the growth rate of the working age cohort and the sex ratio), infrastructure, macroeconomic management, and financial development are especially important for growth. However, their relationship to growth is not linear. Different clusters of fundamentals and policy choices produce different growth performance. We do the same analysis for low-income and high-income countries using the same methodology.

Our paper differs from the existing literature in three important dimensions. First, instead of focusing solely on the unconditional transitions of a country's income status or unconditional 
changes in economic growth rates (as did, for example, Eichengreen et al. (2013); Felipe et al. (2014); and Im and Rosenblatt (2013)), we examine what combinations of fundamentals and policies can separate fast- and slow-growing economies in a given income group. Second, as far as we know, this is the first attempt to employ a non-parametric classification scheme-regression tree and random forest-in analyzing economic growth. The technique allows for a flexible way to discover possible interaction effects among potential growth determinants. Third, as a byproduct of using the regression tree technique, we can handle a large number of potential growth determinants (and their interactions) with ease, tolerate uneven presence of missing data across variables, countries, and time periods, and do not have to make assumptions about the distribution of random shocks.

It is useful to briefly compare our paper with other related ones. Aiyar et al. (2013) examine the impacts of factors such as institutions, demographics, macroeconomic environment, and economic structure on economic slowdown. To deal with the small number of observations and large number of potential right-hand side variables, they use a probit model to include one set of right-hand side variables at a time, which seriously limits the credibility and generalization of their results. Rudengren et al. (2014) discuss the roles of governance, education, and other factors in economic growth. However, they only make some qualitative arguments without providing formal tests or analytical evidence. Using a country's income relative to that of the US, ${ }^{2}$ Jones (2015) calculates the long-run stationary probability for each income group. His result is consistent with the findings in the first part of our paper. Jones (2015) has also examined the importance of institutions and governance on economic growth. We will let institutions be one of the fundamental variables in our analysis.

It is important to point out that the regression tree approach does not directly determine casual effects; it is a classification exercise that looks for combinations of policy and fundamental variables that separates fast growing economies from stagnant or regressive economies. We view this as a step towards identifying causal variables. In other words, if a variable is not found by the regression tree method to be a (statistical) predictor of growth, it is unlikely to be a cause of growth. On the other hand, if a variable is found to be a predictor of growth, additional research possible involving cleaver instrumental variable design that goes beyond the scope of this paperis needed to investigate whether there is a causal link ${ }^{3}$.

Let us also note the relationship between the regression tree approach and the approach to use linear Bayesian Model Averaging (BMA) to identify robust growth correlates. Linear BMA imposes linear relationships between economic growth and potential correlates (or specific deviations from the linearity such as interactions between two variables or a quadratic functional form). In comparison, the regression tree approach allows all such deviations from linearity in a

${ }^{2}$ Less than 5 percent, between 5 and 10 percent, between 10 and 20 percent, between 20 and 40 percent, between 40 and 80 percent, and more than 80 percent.

3 Athey and Imbens (2015) have proposed a way to identify a treatment effect of a single variable in a regression tree framework. This approach has to assume all other attributes as exogenous. This will not work well in our context as there is no strong prior knowledge to allow us to assume that all variables but one are exogenous. 
very flexible way (and the existence of any non-linearity is subject to a statistical test). A variable that is found to be robust under linear BMA may not be robust under a regression tree. Similarly, a variable that is not robust under linear BMA could be found to be relevant for growth under some combinations with other variables in a regression tree.

The rest of this paper is organized as follows: Section 2 discusses the unconditional transitions of income status in the long run; Section 3 presents an analysis of evolving constraints on growth by the technique of regression tree and random forest; Section 4 provides a counterfactual growth scenario analysis; and finally, Section 5 concludes.

\section{2. (Unconditional) Economic Transitions in the Long Run}

We measure income levels by real GDP per capita from the Penn World Table 8.0. Table 3 in the Appendix lists real GDP per capita for 107 economies in 1960, 1980, and 2011. ${ }^{4} \mathrm{We}$ categorize all countries into five income groups: "Extremely Low-Income" (ELI) with real GDP per capita less than or equal to $\$ 1,096$; "Low-Income" (LI) with real GDP per capita of \$1,096-\$2,418; "Lower-Middle-Income" (LMI) with GDP per capita of \$2,418-\$5,550; "Upper-Middle-Income" (UMI) with GDP per capita of \$5,550-\$15,220; and "High-Income" (HI) with GDP per capita greater than or equal to $\$ 15,220$. The threshold of $\$ 2,418$ is equivalent to the World Bank's cut-off line between low-income and middle-income countries defined in 2013. In addition, another category was added, extremely low-income countries, which comprises countries with per capita income below \$3/day in 2005 PPP or \$1,096/year in 2005 PPP terms. The income of the United States in $1960(\$ 15,220)$ was used as the threshold for classifying high-income countries. ${ }^{5}$ Furthermore, the threshold for lower- and upper-middle-income countries was also calibrated so that there are about the same number of countries in the lowerand upper-middle-income categories in 1960, which resulted in a cutoff of $\$ 5,550$. Additional details of the mapping between our cut-off lines and the World Bank's classification can be found in the Appendix.

In Figure 1, we plot log GDP per capita in 2011 against that in 1960. We impose the thresholds that separate middle-income from low-income countries, and high-income from middle-income countries. In terms of overall growth performance from 1960-2011, countries in a given income group fall into one of the following scenarios: 1) those below the 45 degree line, which experienced a negative growth rate; 2) those above the 45 degree line but still belonging to the same income group; and 3) those with a positive growth rate and have moved up to a higher income group. All countries that belonged to the middle-income group in 1960, except for Zambia, enjoyed positive growth rate with more than half of them moving up to achieve high-income status (27 out of 41) in 2011. The scenario for the low-income group is much worse:

\footnotetext{
${ }^{4}$ While the World Bank's GDP in PPP terms is measured based on a single-year PPP benchmark, the Penn World Table uses chained PPPs. 2011 is the latest year included in Penn World Table 8.0.

5 This is lower than the World Bank's threshold for high-income countries $(\$ 19,429)$, since using the World Bank's threshold would result in the US being classified only as a middle-income country in 1960.
} 
63 countries in 1960 started as low-income countries, 29 remained as low-income countries in 2011, among which 8 countries experienced negative growth rate.

All Asian and Pacific economies (in red dots) experienced positive growth rates, with a majority of them managing to move out of low-income status to at least the lower-middle-income group. The Republic of Korea, Singapore, and Taipei,China have burst past middle-income status and attained high-income status.

From Figure 1, the middle-income group does not exhibit stagnant growth for a majority of countries. We probe it further by looking at the short-term transition using a shorter time span starting from 1980. A similar pattern is shown in Appendix Figure 2. All middle-income countries enjoy a positive growth rate while some of the low-income countries experience a negative growth rate. Since a majority of low-income countries also have positive growth, the unconditional probability of being trapped is also low.

After examining growth patterns in absolute terms, we turn to relative measures. As shown in Figure 2, the threshold for low-income countries is $16 \%$ of the US income level. ${ }^{6}$ The threshold for separating upper-middle-income and high-income countries is the 1960 US income level $(100 \%)$.

The countries below the 45 degree line grew slower than the US. Compared to Figure 1, there is less catch-up and more countries remain where they are in terms of their income relative to that of the US. As is well known, some Asian economies managed to move up to the higher-income group even in relative terms. Nonetheless, for those middle-income countries below the 45 -degree line, their growth rates are lower than that of the US and they are getting farther away in terms of relative living standards compared to the US.

Figure 3 plots annual growth rates of countries in 1960-1980, 1980-2000, and 2000-2010 with their initial incomes in 1960, 1980, and 2000, respectively. One important take-away message is that the middle-income countries as a group do not grow more slowly than either the low income countries or high income countries. At each income group, there are countries that do not grow fast, but the proportion of such countries is not unusually high for the middle-income group.

\subsection{Transition Matrix and Ergodic Distribution}

We now investigate transition probabilities of different income groups by introducing the transition matrix and its asymptotic distribution or the Ergodic distribution.

We group countries by their per capita GDP at the beginning of a decade. There are five income groups: extremely low, low, lower-middle, upper-middle, and high. For each income group, we compute the probabilities that a typical country moves to each of the possible income groups over a decade. These probabilities are summarized by a transition matrix in Table $1 .^{7}$

${ }^{6} \$ 2,418 / \$ 15,220$ in 1960 term.

7 The decade average transition matrix is estimated based on the 5-decade transition matrices from 1960 to 2010 by employing a numerical optimization program. Instead of taking the simple average for the five transition matrices (which suffers from Jensen's Inequality), we estimate a transition matrix that can give us an exact five decade duration transition matrix (entry in 1960 and exit in 2010) by taking its power 5. 
The number in a given cell reports the probability that a typical country with an income status in the row moves to the income status in the corresponding column over a decade. For example, the first cell says that an extremely low-income country has an $82 \%$ probability of remaining in the same income status after a decade, and the second cell says it has an $18 \%$ probability of becoming a low-income country in a decade. The remaining cells in the first row indicate that there is zero probability of moving up any further in a decade. A country that started as an upper-middle-income country has a $70 \%$ probability of staying in the same income status and $30 \%$ probability of moving up as high-income country at the end of the decade.

Based on the transition matrix, we can see that for all the non-high-income groups, the probability of moving up to a higher-income level in one decade is greater than $15 \%$. The next question is whether countries in any income group can end up in the high-income group eventually. To address this question, we employ the Ergodic distribution. ${ }^{8}$ As shown in the last row of Table 1, in the long run, regardless of a country's original income status, it will always end up in the high-income group (with probability of 1). ${ }^{9}$ In other words, in the long run, there is neither a low-income trap, nor a middle-income trap. The only trap we can see in the data is a high-income trap. That is, once a country reaches high-income status, it is expected to stay there forever.

The Ergodic distribution tells us the distribution of income status across countries over the very long run. But how long does it take to reach the very long run? From the transition matrix, we estimate that it will take 44 decades for all the extremely low- and low-income countries to move up to the next income level or higher, while it will take 48 decades for all countries to achieve either an upper-middle-income or a high-income status.

We can also compute, based on the transition matrix, the number of decades it takes for a given percentage (e.g., $50 \%$ or $90 \%$ ) of countries in an income group to move out of their current status and into higher income groups.

We summarize the results in Table 2. For extremely low-income countries, it takes 4 decades for half of them to move to higher income groups. Similarly, for low-income, lower-middle-income, and upper-middle-income countries, it takes 3, 3, and 2 decades, respectively, for half of the countries to move to a higher-income status.

If we want to see $90 \%$ of the countries in a group move to higher incomes instead of $50 \%$, naturally, the required durations would be longer. For the four developing country groups from the extremely low-income to the upper-middle-income group, it takes 14, 12, 8, and 7 decades respectively, to move into the next income level or higher.

Two features of the results are worth emphasizing. First, if we want to know whether most middle-income countries can expect to achieve today's US living standard, the answer is yes, sooner or later. Second, if we want to know whether middle-income countries face a greater challenge in moving up their income status than low-income countries, the answer is no. It takes

\footnotetext{
${ }^{8}$ Ergodic distribution matrix $=$ Transition Matrix ${ }^{+r}$. Empirically, we use power 2000 to approximate the Ergodic distribution matrix.

${ }^{9}$ We also check the robustness of the results by using a transition matrix with 5 decades as the duration (1960-2010). The result does not change.
} 
less time for middle-income countries to move up than for the same proportion of low-income countries to do the same. In this sense, the MITH (the "middle-income trap hypothesis") is a myth - it is not supported by the data.

We have extended this discussion to consider: (i) the transition trend based on decade-specific transition matrices, and (ii) the effect of financial crisis. The results can be found in the online Appendices. Crucially, the qualitative results stay the same.

\subsection{Ergodic Distribution Analysis on Convergence in relative terms to the US}

So far, we have discussed the transitions based on absolute terms. Next, we assess the transition pattern relative to the US income level (which is a moving target). We divide the groups into four categories: $16 \%$ of US real per capita income as low-income, $16 \%-36 \%$ of US real per capita income as lower-middle-income, $36 \%-75 \%$ of US income as upper-middle-income, and $75 \%$ of US income and above as high-income indicating catch up with the US. ${ }^{10}$

Table 3 presents the decade average transition matrix relative to US income from 1960 to 2010. For the low-income group, the probability of entering the lower-middle-income category relative to the US is $8 \%$. The probability for a lower-middle-income country to catch up with upper-middle-income country is $15 \%$ and that for an upper-middle-income country to catch up with the high-income group is $22 \%$. In relative terms, the middle-income countries enjoyed higher probability to move up compared to low-income country and no obvious slowdown in the transition process after countries enter a middle-income status.

The last row of Table 3 shows the corresponding Ergodic distribution. The last column of the Ergodic distribution shows that $67 \%$ (1-33\%) of countries cannot exceed $75 \%$ of US income in the long run. In other words, in relative terms to US income, a certain proportion of countries in the middle does not rise to the top. (It is important to point out, however, that their living standard can nonetheless catch up with and even surpass that of Americans today).

Should we care about the transition probability of absolute living standard or relative living standard? From the viewpoint of well-being of the people in developing countries, the absolute living standard arguably is more relevant. From the viewpoint of political leaders who think of their power on the world stage, or for people whose utility is a negative function of relative consumption, the relative income can matter too.

Finally, to examine the relative challenges faced by countries in the middle versus those by countries in the bottom, the transition matrix in Table 3 is informative. For countries in the relative bottom (with income less than $16 \%$ of the US), there is only $8 \%$ chance to move up after a decade. For countries in the relative lower middle, the odds are better and $15 \%$ of them can be expected to move up after a decade. For countries in the relative upper middle, the odds are better still and $22 \%$ of them can be expected to move up after a decade. Therefore, even if we define income in relative terms, the notion that (relative) middle-income countries face a tougher chance

\footnotetext{
${ }^{10}$ The reason we have $16 \%$ as the cut-off line is to be consistent with the absolute analysis, in which, $\$ 2,418$ (the line to differentiate low-income and lower-middle-income in 1960) divided by $\$ 15,220$ (US income in 1960) is 0.16 . The relative lower-middle-income line is 0.36 (dividing $\$ 5,500$, the line differentiating lower-middle- and upper-middle-income, by $\$ 15,220$ ). We choose $75 \%$ as the line to indicate a reasonable range with the US.
} 
of moving up the ladder than (relative) poor countries is not supported by the actual experience of the countries.

\subsection{Long-horizon Analysis with Maddison Data}

In Maddison's data, GDP per capita of the US in 1990 international Geary-Khamis dollars for the year 1960 is $\$ 11,328$. Aligning with the absolute cut-off lines measured by 2005 PPP international dollars, we use $16 \%, 36 \%$, and $100 \%{ }^{11}$ of the US level to calculate the cut-off lines for income groups in 1990 international Geary-Khamis dollars. These correspond to the following categories: low-income (less than \$1,812); ${ }^{12}$ lower-middle-income $(\$ 1,813-\$ 4,078)$; upper-middle-income $(\$ 4,079-\$ 11,327)$; and high-income (\$11,328 and above).

Table 4 shows the 50-year duration transition matrices for 1850-1900, 1900-1950, and 1950-2000. For each 50-year period, we included countries with available data for both the entry year and exit year. Compared with 1850-1900 and 1950-2000, in 1900-1950, the low-income group and lower-middle-income group had the highest probability of moving on to the next income level or higher. For the period 1950-2000, the probability for lower-middle-income countries of moving to high-income is $37 \%$ while the probability for upper-middle-income countries of achieving high-income status is $81 \%$. The Ergodic distribution is consistent with the Ergodic distribution results using the Penn World Table 8.0 data. The probability for all income groups ending up in the high-income group is $100 \%$. For some countries, there were income decreases for some sub-periods. For example, the income of Argentina dropped from $\$ 8,206^{13}$ in 1980 to $\$ 6,433$ in 1990 . However, when we examine the transition using the longer 50-year duration matrix, it still enjoyed a positive trend with $\$ 2,756$ for $1900, \$ 4,987$ for 1950 , and $\$ 8,581$ for 2000 . That is, even with some countries experiencing short-term backward movements in income, in the long run, the ergodic distribution yields the scenario where all groups end up in the high-income group for sure.

Different from Acemoglu et al. (2001) who documented a growth reversal for many colonized countries in Africa, Asia, and Latin America, our unconditional and conditional analysis are both based on the common features of groups at different income levels (low-income and middle-income): when the rare shocks such as colonization cannot enter into the model as a common feature, it will not affect the average performance of the group. Our findings from the unconditional transition matrix analysis support the conclusion that middle-income countries do not face lower probabilities of moving up compared to what low-income countries face.

Rodrik (2015) and Felipe et al. (2014) raise the intriguing possibility that development might have become more difficult over time. More precisely, they show that the manufacturing share in total employment peaks earlier for today's developing countries than for today's advanced countries. If productivity growth tends to be faster for manufacturing activities than for non-manufacturing activities, then one may conjecture that growth may be harder for today's

\footnotetext{
$11100 \%$ of the US income used as the high-income cut-off line is consistent with the analysis in absolute terms discussed in section 2.1 using the Penn World Table.

12 This corresponds to $\$ 2,418$ in the Penn World Table data.

13 In 1990 International Geary-Khamis dollars.
} 
developing countries. Note that these authors do not directly test whether the (upward) transition probability has deteriorated over time. In our extension, we directly compute and examine how the transition probability changes over time. We find no support for the notion that the development has become more difficult over time. From 1850-1900, only 25\% of the lower-middle-income countries at the beginning of the period became upper-middle-income by the end of the 50-year period, and none became high-income over this period. In comparison, from 1900-1950, 79\% of the lower-middle-income countries at the start became upper-middle-income by the end (though none became high-income). From 1950 to 2000, 74\% of lower-middle-income countries at the start have moved up to higher-income brackets by the end of the 50-year period, half of which actually attained high-income status. Of course, it is always possible for the transition probabilities to change qualitatively in the future; we won't be able to formally test out-of-sample predictions.

\section{Evolving Constraints to Growth: A Perspective from Regression Trees}

One implicit assumption in the transition matrix analysis is that the transition probabilities from one income status to another are the same for all countries within a given income group. However, for real growth progress, there is heterogeneity across countries. These dimensions of heterogeneity could be very interesting if they are systematically related to fundamentals or

policy choices. In this section, we investigate factors affecting economic growth and their relative importance at different stages of development. Based on this analysis, we will argue that not all middle-income countries are the same. While many are expected to grow fast, others could be near stagnant, and some could even move backward and revert to low-income status. Furthermore, there are identifiable combinations of country characteristics that would place countries into these different buckets (in a probabilistic sense).

The extant growth literature suggests a long list of factors that have been hypothesized by researchers, policy makers, and practitioners as important factors for growth, especially for low-/middle-income countries. Some papers, such as Aiyar et al. (2013) and Rudengren et al. (2014), made qualitative arguments about the roles of governance and education in economic growth without providing formal tests or analytical evidence. Many potential determinants of growth could be summarized by the so-called Washington Consensus or, for a more recent rendition by a development practitioner, the "eight key actions for development" by Nakao (2014). One potential growth determinant that emerges from a more recent literature is the sex ratio for the pre-marital age cohort, which we will explain below.

The variable to be explained is growth performance at the country-decade level starting from the 1960s. For most regressors, we look at the values at the beginning of a decade (so that the regressors are pre-determined). Some variables are available for a shorter time span. The regression tree technique can work with an unbalanced panel.

\subsection{Variables That Could Alter Growth}


We now discuss variables that may separate fast-growing and slow-growing countries. This list is guided by the vast existing literature on determinants of growth. The explanatory variables include both structural factors (e.g., demographic factors, human capital, etc.) and policy choices (e.g., debt level, financial development, openness, etc.) In the following discussions, we first discussed the structural factors and then the policy choices.

It is important to note at the onset that some plausible determinants of growth are not included in the examination here due to measurement issues. For example, political leaders' vision is identified by Nakao (2014) as one of the key growth determinants. However, we are not aware of a reliable data source that measures the quality of leaders' vision across countries or over time. As a result, we have to leave it out of the analysis here.

Initial income level is commonly accepted as a determinant of the growth rate, as it is implied by the Solow growth model and confirmed by a long list of empirical papers (see a summary by Barro and Sala-i-Martin (2004)). Besides the Solow model, the pattern can also be justified by evolving sources of growth as a function of initial income. Low-income countries benefit from adopting existing technologies created in more developed countries and thus enjoy higher growth rates. As they experience productivity advancements, they move closer to the technology frontier and are compelled to innovate rather than to merely imitate, which is harder, and so their growth rates decline. Therefore, in our analysis, we expect countries with higher initial incomes to have lower growth rates, and those with lower initial incomes to have higher growth rates. This expectation is in line with findings in the literature. For example, Pritchett and Summers (2014) argued that there is a strong "regression to mean" in growth rates across countries. Real GDP per capita at the beginning of each decade is used as the initial income.

Demographic variables have three broad categories: (a) ratio of the working age cohort in total population, (b) growth rate of the working age cohort, and (c) sex ratio of the pre-marital age cohort. The first two categories have commonly been considered as basic driving factors of economic growth. The contributions of population age structure come from two channels: higher labor supply and higher saving rates as pointed out by Bloom et al. (2007). Empirical evidence has likewise been documented by Bloom et al. (2000) and Bloom et al. (2003). We include the share of population 15-64 years old (labor force age population share) and the labor force growth rate (the difference between the natural logarithm of the population aged 15-64 at the end and at the beginning of the decade) as two of the demographic variables. The data comes from the World Bank's World Development Indicators (WDI).

The sex ratio for the pre-marital cohort requires some explanation. Wei and Zhang (2011a, 2011b, and 2012) and Du and Wei (2013) suggested marriage market competition as a key motivation for savings, labor supply, and work effort - a higher level of wealth relative to one's competitor in the dating/marriage market gives one an edge in attracting the opposite sex. This is true regardless of the sex ratio. But in cases of a higher male/female ratio in the pre-marital age cohort, a certain fraction of males will not be able to find a girlfriend or wife. The drive to create and accumulate physical wealth becomes stronger. This implies that a higher sex ratio (or, more precisely, deviations from a balanced sex ratio in either direction) tends to be associated with a higher rate of economic growth. 
A few points are worth noting. First, the behavior response to a change in the sex ratio can come from parents with unmarried sons, not just the sons themselves. In fact, the response by the parent cohort (with children aged 0-29) is likely to be quantitatively more important than that of the children themselves. Second, even though parents with daughters may view an increase in the sex ratio as a favorable development for their daughters, they may not reduce their work effort or entrepreneurial tendency enough to offset the reactions by parents with sons. Here is the reason. Even though the probability that their daughters will find a husband has increased, they may not want their daughters to find just any husband. The top $\mathrm{N}$ best young men are fixed in number; but the top $\mathrm{N}$ young men are wealthier in an economy with a higher sex ratio than without it. As a result, the reward for the daughters to be matched with the top $\mathrm{N}$ men is also higher. So parents with daughters may also need to compete among themselves.

Wei and Zhang (2011b) provided evidence from the PRC. First, families with an unmarried son living in a region with a high sex ratio imbalance are more likely to work more days in a year and choose to be an entrepreneur or self-employed. Second, the growth rate in the count of privately owned firms is higher in regions with a stronger sex ratio imbalance. Third, in panel regressions across Chinese provinces from 1990-2010, GDP growth rates tend to be higher in regions with a high sex ratio.

Note that the logic of the hypothesis should apply to countries other than the PRC too. Economies such as Viet Nam, India, the Republic of Korea, and Taipei,China also have unbalanced sex ratios. Indeed, Du and Wei (2013) reported cross country evidence that higher sex ratios are associated with higher savings rates. To account for this demographic hypothesis, we include the sex ratio (males/females) for the age cohort of 0 to 29.

It is important to note even if we find a positive association between sex ratio imbalance and economic growth rates, we will not advocate engineering gender selective abortions or an unbalanced sex ratio in general to promote growth. Even though a higher sex ratio may lead to faster GDP growth, it does not necessarily lead to a higher level of welfare. The extra GDP growth comes from the desire of the parents with sons to use the accumulation of wealth to reduce the probability of their sons becoming involuntary bachelors. Yet, for the society as a whole, the total number of young men who cannot get married is independent of the wealth accumulation. In this sense, the extra sacrifice that the parents have to make to accumulate wealth may lead to a reduction in welfare. (In other words, the extra GDP growth induced by a sex ratio imbalance may be a case of immiserizing growth.) This is the point made by Wei and Zhang (2011b).

To represent human capital, we use average years of schooling of the population from the Barro-Lee database. That better education is associated with higher growth is a common assertion. The empirical support suggests two types of channels. First, Barro (1991) may be the primary scholar to document a positive correlation between growth rate and initial human capital proxied by initial school-enrollment rates for 98 countries during the period 1960-1985; Mankiw et al. (1992) used the percentage of working-age population that is in secondary school to approximate the rate of human-capital accumulation rate in an augmented Solow model and found a significant contribution from human capital to economic growth. Benhabib and Spiegel (1994) explained the 
positive relationship using an endogenous growth model in which technological progress is a function of human capital. Second, education can provide a pre-condition for other factors promoting growth. For example, Borensztein et al. (1998) found that FDI is helpful to growth only if the population is sufficiently educated. Another group of papers uses a calibration-based development accounting approach. For example, Caselli and Ciccone (2013) computed the increase in output that can be generated by more schooling which they interpret as an upper bound effect. We use years of schooling as a measure of human capital. An important qualification is that such a measure does not fully capture quality of education (Hanushek and Woessmann, 2008). Unfortunately, test scores from internationally comparable tests, a common variable used to adjust for quality, are not available in time series.

Inequality is considered by Nakao (2014) as a potential drag on growth. The empirical literature on the relationship between inequality and growth produces mixed results. While Forbes (2000) found that, in a panel regression, a rise in inequality tends to be associated with a pickup in the subsequent growth rate, Deininger and Squire (1998) and Barro (2000) find that higher inequality retards growth in poor countries but encourages growth in rich countries. We include the income share held by the bottom $40 \%$ people from the World Bank's World Development Indicators as a measure of inequality. The closer this share is to $40 \%$, the less inequality there is. This indicator measures the income share directly, and is easier to understand than the standard Gini coefficient. The income share held by the bottom $40 \%$ people has been chosen by the World Bank as an official measure of the degree of broadly shared prosperity since 2013 (World Bank (2013)).

The effect of resource abundance on growth is controversial. On the one hand, better endowment in natural resources provides more natural wealth to the country. On the other hand, the literature on "Dutch Disease" and "natural resource curse" also suggest mechanisms in which natural resource abundance could derail a country's long term growth by either making the manufacturing sector uncompetitive or by inducing political instability or expropriations. We use an "oil exporter" to denote major oil exporters for those countries whose fuel exports exceed either $40 \%$ of their total exports or $15 \%$ of their GDP. Data come from the World Bank's World Development Indicators. A given country could be classified as a major oil exporter in one decade but not in the others. Out of 488 country-decade combinations, 36 observations were labeled as oil exporters.

The global economic environment is intended to capture the overall trade and investment climate faced by developing countries. We construct an indicator using the US growth rates before 1980 and the population-weighted average growth rates of Japan, Germany, and the US after 1980. The growth rates of the advanced economies, measured this way, are $3.4 \%$ for the $1960 \mathrm{~s}, 2.2 \%$ for the $1970 \mathrm{~s}, 2.1 \%$ for the $1980 \mathrm{~s}, 2.6 \%$ for the $1990 \mathrm{~s}$, and $0.7 \%$ for the $2000 \mathrm{~s}$.

Infrastructure is often claimed to be a key input in a country's investment climate. When Prime Minister Modi of India and President Jokowi of Indonesia came to power in 2014, they both stressed investing in infrastructure as a key to lifting their respective countries' growth rates. Straub (2008) suggests that infrastructure promotes growth directly through productivity improvements. Indirect channels include: labor productivity improvement by reducing time to 
commute, health and education improvement, and economies of scale and scope. IMF's World Economic Outlook (2014) also found increased public infrastructure investment to raise output in both the short and long term, particularly during periods of economic slack and when investment efficiency is high. Following the recent trend of using direct measures of infrastructure development rather than infrastructure investment (see Egert et al. (2009) and Calderón et al. (2014)), we use the indicators developed by Calderón et al. (2014), which include: (1) electricity generating capacity in gigawatts per thousand workers; (2) total length of paved roads in kilometers per thousand workers; and (3) total length of rail in kilometers per thousand workers.

For macroeconomic policy environment, we include inflation rate, government debt as a share of GDP, and the number of macro or financial crises in a decade. The CPI inflation come from the World Bank's World Development Indicators. The others are derived from Reinhart and Rogoff (2009) and extended using more recent data. The government debt/GDP is the ratio of the gross central government debt to GDP. The total number of crises is the sum of currency crises ${ }^{14}$ and banking crises ${ }^{15}$ within a decade.

Three dimensions of economic openness are considered: the share of exports plus imports in GDP (trade share), the share of gross FDI inflow to GDP, and the share of gross non-FDI inflow to GDP. The trade share is from the World Bank's World Development Indicators. The FDI and non-FDI inflows are from Bluedorn et al. (2013). Gross non-FDI inflows is the sum of gross portfolio equity inflows, portfolio debt inflows, and other inflows. ${ }^{16}$ While a vast literature confirms a positive association between trade openness and growth, but causality interpretation is more controversial (see Rodgriguez and Rodrik, 2001). Frankel and Romer (1999) and Feyrer (2009) propose instrumental variables for openness and conclude that trade openness causally raises income.

There are several channels for FDI to affect growth, including improving trade openness (Balasubramanyam et al. (1996)) and improving financial markets (Alfaro et al. (2003)). Forbes and Warnock (2012) argue that compared with net FDI inflows, gross capital inflows and outflows (allowing differentiation between domestic and foreign investors) have more information on crisis and capital flow volatility. We use stock of FDI liability as constructed by Lane and Milesi-Ferretti (2007). Because FDI flow data are more readily available for more countries and more years, we also adopt a measure of stock of inward FDI by cumulative inflows over the four years before a decade starts (for example, sum of inflows in 1967-1970 for the decade starting in 1970). Similarly, we construct a measure of stock of non-FDI liabilities.

\footnotetext{
${ }^{14}$ Currency crisis is defined as: currency crashes (an annual depreciation versus the US dollar (or the relevant anchor currency - historically the UK pound, the French franc, or the German DM, and presently the euro) of 15 percent or more); currency debasement (a reduction in the metallic content of coins in circulation of 5 percent or more or a currency reform where a new currency replaces a much-depreciated earlier currency in circulation).

15 A banking crisis is defined as a bank run that leads to closure, merger, or takeover by the public sector of one or more financial institutions; and if there are no runs, the closure, merger, takeover, or large-scale government assistance of an important financial institution (or group of institutions), that marks the start of a string of similar outcomes for other financial institutions.

${ }^{16}$ Gross derivative inflows are excluded from non-FDI inflows because of its limited coverage.
} 
Financial development has been frequently argued as an important driver for economic growth. For example, Levine (2005) and Demirgüç-Kunt and Levine (2008) conclude that a well-functioning financial system plays an independent role in promoting long-run economic growth. In the interest of obtaining a relatively long time series, we select four indicators from the Global Financial Development Database constructed by Čihák et al. (2013): (1) the number of commercial bank branches to represent the degree to which individuals and firms can use financial services (a proxy for financial access) $;^{17}$ (2) private credit to GDP to represent the size of financial institutions and markets (financial depth); (3) lending-deposit rate spread to represent efficiency of financial intermediaries in intermediating resources and facilitating financial transactions (efficiency); and (4) ratio of bank credit to bank deposit, to represent the stability of financial institutions (stability).

The potential importance of institutions and political stability in growth is recognized and indeed emphasized in the recent literature (see, for example, Glaeser et al., 2004). Good political institutions (low expropriation risk) provide good incentives for the private sector to invest in human and physical capital, which in turn contribute to growth. Well-known papers include Hall and Jones (1999), Acemoglu et al. (2001, 2002), Easterly and Levine (2003), Dollar and Kraay (2003), and Rodrik et al. (2002).

One of our key measure of political institutions is constraint on executives - the extent of constitutional restrictions on the executive power from legislative, judicial, or other political bodies - from Henisz $(2000,2002)$. But we have also tried other similar measures such as "constraint on executives" from Polity IV project, and "checks" from the World Bank's database on political institutions (see Beck et al. 2001). These measures are highly correlated with the Henisz measure (with pairwise correlations exceeding 0.7).

Other measures of political institutions that we include are: (a) the economic freedom index proposed by Gwartney et al. (2015), summarizing information on the size of government, legal structure, access to sound money, freedom to trade internationally, and regulation of credit, labor, and business, (b) democracy scale (from Polity IV), (c) corruption perception index from Transparency International, and (d) ideological polarization from World Bank's database of Political Institutions, which measures maximum difference of orientation among government parties (see Beck et al. 2001).

Political instability could hurt growth. Alesina et al. (1996) documented that in countries and time periods with a high propensity of government collapse (political instability), growth is significantly lower than otherwise. Jong-a-Pin (2009) and Aisen and Veiga (2013) also conclude that internal regime instability reduces growth. We employ two indicators: (a) domestic conflicts from Cross-National Time-Series (CNTS) Data Archive and (b) political stability and absence of violence (PSAV) from World Bank's Governance Indicator dataset to represent political instability. The first variable is a count of domestic conflicts in a decade such as assassinations, strikes, guerrilla warfare, government crisis, purges, riots, revolutions, and anti-government

\footnotetext{
${ }^{17}$ However, since bank branches per 100,000 adults are only available starting 2003, and our regression tree analysis requires the entry value for each decade, we have to drop this variable in our regression tree analysis.
} 
demonstrations. Higher values of the indicator signal more conflicts. The second variable measures the government's ability to carry out its declared programs and its ability to stay in the office. These two measures have some overlaps.

To summarize, we have 27 variables in total which can be grouped in the following way:

Demography:

(1) working-age population share (15-64 years old), (2) working age population growth (15-64 years old), (3) sex ratio (male/female) from age 0-29;

\section{Infrastructure:}

(4) paved roads in km per 1,000 workers, (5) power generating capacity in gigawatts per 1,000 workers, (6) railway in km per 1,000 workers;

\section{General Economic Environment:}

(7) years of schooling, (8) log initial income level, (9) global growth rate, (10) inflation, (11) the number of years in a decade with either banking or currency crises, (12) government debt share in GDP, (13) trade share in GDP, (24) income share of bottom 40\%, (15) an oil exporter dummy;

\section{Financial development and financial openness:}

(16) domestic credit to private sector as a share in GDP, (17) bank credit to deposit ratio, (18) bank lending-to-deposit rate spread, (19) stock of FDI measured by cumulative inward FDI in the four years (as a share of GDP) immediately preceding a decade, (20) stock of non-FDI liabilities measured by cumulative non-FDI inflows (as a share of GDP) immediately preceding a decade;

\section{Institutions and Politics:}

(21) Constraint on executive power, (22) ideological polarization, (23) economic freedom, (24) corruption perception index, (25) democracy scale, (26) domestic conflict, and (27) political stability and absence of violence.

We use real GDP per capita from the Penn World Table 8.0 to construct economic growth at the country-decade level. It is important to acknowledge that we do not deal with possible endogeneity of the regressors. In the empirical literature with more standard regression techniques, creative instruments have been proposed for selected growth determinants. For example, geography has been proposed as an instrument for trade openness (Frankel and Romer (1999)), and colonial origin of a developing country has been proposed as an instrument for quality of institutions/check and balance on the executive power (Acemoglu et al. (2001)). There are no well-developed techniques to address the endogeneity issue in a regression tree framework. The endogeneity issue is likely to be less serious for the structural factors but more serious for the policy variables. If we were to use more standard regression techniques, we still would not be 
creative enough to have instrumental variables for all the potentially endogenous variables. Therefore, the nature of our exercise is a classification exercise: what combinations of variables tend to be associated with fast, slow, or negative growth rates. The endogeneity issue for all variables in a regression tree framework will need to be investigated in future research.

To mitigate a possible endogeneity concern, we use initial values of all variables at the beginning of the decade, except for the growth of the 15-64 age cohort, global growth rate, and the frequency of banking or currency crises in a decade.

The dataset includes 120 countries and 5 decades. The first decade is 1960-1969. A country-decade is included in the sample if at least 12 variables are available ${ }^{18}$. This results in a total of 488 observations.

\subsection{Box Whisker Plot and Pair-wise Correlation Analysis}

For each income group, a Box Whisker Plot is drawn for each variable and presented in Figure 1 in the appendix. While the middle-income countries have higher median growth rate (annualized over a decade) at 29\%, the low-income countries have a lower median growth at $11 \%$, but with larger variations across countries. There are clear strong associations between income levels (low/middle/high) and years of schooling, political constraints, population share of labor-force age, electricity generating capacity, railway, domestic credit to private sector, and sex ratios for age $0-29$. On average, higher levels of each factor are associated with a higher average income.

For inflation, the median levels of the low-income and middle-income groups are close to each other, with a higher degree of variation among the middle-income group. For trade share, all three income groups share similar median levels, with the middle-income group having the largest variation. For gross stock of inward FDI and cumulative non-FDI financial flows, the high-income group has the highest median and largest variation. For domestic conflicts, the low-income and middle-income groups experience worse situations than the high-income group. For government debt, the high-income group has the highest median level at around $41 \%$ of GDP. For the number of years in a decade that a country has financial (currency or banking) crises, the high-income group and the middle-income group have the same median at 2. For labor force growth, the low-income group has the highest growth rate at $27 \%$ over a decade while the high-income group has the lowest decade growth at $7 \%$ over a decade. The high-income group has the highest median of the bank credit to deposit ratio at $107 \%$ while the low-income group has the lowest median. On the opposite end, the low-income group has the highest median of bank lending-deposit rate spread (indicating a high degree of financial frictions) while the high-income group has the lowest median.

The Box Whisker Plots reveal clearly heterogeneity in variables among different income groups, indirectly supporting the hypothesis that different factors matter for growth for countries in different income groups. To obtain some initial impressions, we present pair-wise correlations for low-income and middle-income countries in Appendix Table 1. The red color highlights

${ }^{18}$ Out of the first 22 potential predictors among the 31 variables. 
relatively strong relationship - correlations exceeding 0.2 in absolute values (the first row). The second through the last rows show the correlations between factors. The green color suggests a relatively strong relationship - correlations exceeding 0.4 in absolute values. As shown in red highlight, different variables are correlated with the growth rate for different income groups: (1) for the low-income group, inflation, years of schooling, political constraints, share of population 15-64 years old, government debt share, crisis, FDI inflow, non-FDI inflow, and sex ratio of age 0-29 have higher correlations with growth than other factors; and (2) for the middle-income group, years of schooling, income share of bottom 40\%, share of population 15-64 years old, government debt share, crisis, growth of population 15-64 years old, gross FDI inflow, and lending-to-deposit rate spread have relatively higher correlations.

The correlations provide some initial hint that conditional on the stage of development, driving factors of economic growth may vary among income groups. We also see that correlations between factors have different patterns across countries with different income levels (as shown in green color). The relatively high correlations among some factors suggest multicollinearity, which would be a problem for linear regressions. However, the regression tree technique we employ below is not undermined by collinearity.

\subsection{Conditional Regression Tree Analysis}

The regression tree analysis is a machine learning method pioneered by Breiman et al. (1984) and refined in the subsequent literature. The general idea of the technique (in the context of growth prediction) can be described in the following way: the algorithm searches for all possible binary splitting points for each predictor (i.e., the independent variables we consider to affect economic growth), and chooses the one split point of the predictor that yields the highest gains in predicting growth and uses that particular predictor and splitting point to grow two "children branches" from the "parent node." Following the same procedure, the algorithm searches and splits each of the children nodes until any further splitting does not yield any gain in improving predictability. In the final tree structure, each of the observations will end up in one of the ending nodes. The predicted growth for each end node is simply the average of the growth of country-decades falling into that node. Therefore, for prediction purposes, we first determine which ending node a country will be located based on the values of its fundamentals and then the average growth rate in that ending node is assigned to be the predicted growth for that country.

Durlauf and Johnson (1995) were the first in applying a(n) (early generation of) regression tree approach to economic growth. But they consider only two conditioning variables: initial income and literacy rate. Their key point is that multiple growth regimes are a better characterization of the data than a single regime.

The Conditional Inference Regression Tree, proposed by Hothorn et al. (2006), is a refinement of the Regression Tree Analysis that introduces hypothesis testing in deciding each split. In particular, a split is made if one can reject the null hypothesis that the proposed split does not improve the predictive power. Because it makes a split of one predictor conditional on other correlated predictors, it overcomes criticisms of the traditional regression tree analysis that favors the choice of correlated predictors to do the splitting method. 
In the Conditional Inference Regression Tree, searching for the best predictor to make the split and searching for the optimal cut-off split value are conducted separately. First, based on linear statistics proposed by Strasser and Weber (1999), the relation of a variable to the response assessed by permutation tests follows a $\chi^{2}$ distribution. The null hypothesis is that there is no association between a predictor and the response. With a smaller p-value, the probability of incorrectly rejecting the null hypothesis is lower. Therefore, in the first step, the variable with the smallest p-value is chosen to do the split. In the second step, the best cut-off point for the most significant variable chosen in step one is determined. For each of the two branches associated with the first split, another variable with the strongest association with the response is searched from among all the variables. The remaining branches of the tree will grow in the same fashion. To grow the conditional inference tree, we require that all splits have p-values of 0.05 or smaller, ${ }^{19}$ a minimum number of observations of 8 for each ending node, and a minimum size of 20 in a branch before any split.

Figures 4 and 5 present the conditional regression trees for low-income and middle-income countries, respectively. ${ }^{20}$ On a given tree, the variables used for each split and the associated p-values are labeled in each splitting node. For each split, the branch to the right indicates the outcome when the values of the splitting variable are higher than a threshold value of the parent node, while the branch on the left indicates the outcome when the values are lower than the threshold. The ending nodes, shaded in grey, present the predicted growth rate with the relevant combination of variable values, with the number of observations also listed. The predicted growth rates are average annual growth rates in a decade.

Using the middle-income group as an example (Figure 5), the variable found optimal by the algorithm to do the first splitting is the share of labor force in the population. The splitting value is $58.47 \%$. Any country-decade with such share exceeding the threshold is classified to the group on the right branch. The share of working age population in total population has competed with all other variables in explaining the variation of growth and is found to yield the highest explanatory power, that is, $\left(\sum_{\mathrm{i} \text { with pop }<58.47 \%}\left(\mathrm{~g}^{\mathrm{i}}-\overline{\mathrm{g}}_{\text {left }}\right)^{2}+\sum_{\mathrm{j} \text { with pop } \geq 58.47 \%}\left(\mathrm{~g}^{\mathrm{j}}-\overline{\mathrm{g}}_{\text {right }}\right)^{2}\right)$ yields the smallest value among all possible variables, where $\mathrm{g}^{\mathrm{i}}$ is the growth rate of country-decade $i$ and $\bar{g}$ is the group average growth rate. After the first splitting, all variables are in competition to do the next splitting until the regression tree reaches the stopping criteria. By doing this systematically, all the country-decade observations that are classified in the same ending nodes share the same range of explanatory variables and have similar growth rates. The average growth rate of each ending nodes is the predicted growth rate by the empirical model (the result of the regression tree approach) for a particular set of structural factors and policy choices.

If there is a threshold effect, an advantage of the conditional tree approach is to search for and identify it by hypothesis testing. In comparison, most papers in the existing literature that

19 The estimation is carried out with the package party() in R.

${ }^{20}$ We skip the investigation of high-income countries so as to focus the analysis on low-income and middle-income countries. 
study a threshold effect, such as Reinhart and Rogoff (2009), pre-impose a particular value of the threshold, which necessarily involve elements of arbitrariness.

The regression tree technique deals with the threshold effects and interactive effects in a flexible way. It allows one variable to contribute to growth only after some other variable reaches certain levels. For example, still using Figure 5 as an example, does a relatively low government debt/GDP ratio (lower than $31.8 \%$ ) help with growth? The regression tree results say that the answer depends: it is true only when a favorable demographic condition is fulfilled (the share of working age cohort is greater than 58.5\%) and for relatively poor countries (the GDP per capita is lower than $\$ 5,437$ ) (see the ending node labelled no. 11).

\section{For Low-Income Countries}

We pool extremely low-income and low-income countries together and label them as one low-income group. As shown in the Conditional Inference Tree in Figure 4, among all the variables we included in the analysis, the important variables for categorizing their growth performance include: demographics (share of population 15-64 years old, growth of population 15-64 years old, and male to female sex ratio of age 0-29), macroeconomic environment (, economic freedom and government debt share to GDP), openness (FDI inflow in the three years prior to the beginning of the decade) and infrastructure (paved road in kilometers per thousand workers).

Based on the ending node results, we further categorize countries into three groups: progressive (with expected annual growth rate higher than 3\%), near-stagnant (with expected growth rate between 0 and $3 \%$ ), and regressive (with expected negative growth rate) countries. For progressive countries, two combinations of variables produce relatively high growth (labeled with blue circles): Conditional on favorable demographics (share of population 15-64 years old higher than 53.4\%), if the country has an imbalanced sex ratio of the pre-marriage group (sex ratio of age 0-29 higher than 0.99 ) and with a labor force population growth in a decade greater than $21.3 \%$, their expected annual growth rate is $4.3 \%$; while if the labor force population growth is not favorable, a higher share of population 15-64 years old (above 57.8\%) can yield an annual growth rate of $3.69 \%$. When the countries have less favorable demographics (share of population 15-64 years old lower than 53.4\%), but have a better macroeconomic environment (economic freedom greater than 3.9) and sound infrastructure (paved road higher than $1.59 \mathrm{~km}$ per thousand workers), they can expect an annual growth rate of $3.1 \%$.

There are three groups with alarmingly negative expected growth rates (labeled with red triangles). One negative growth rate at $-3.0 \%$ is featured with unfavorable demographics (share of population 15-64 years old lower than 53.4\%) and an unfavorable macroeconomic environment (the economic freedom lower than 3.9); another negative growth rate of $-1.24 \%$ shares common demographic features as the previous scenario but with higher government debt (higher than 23.7\%) and poor infrastructure (paved road per thousand workers lower than 2.26 but higher than 1.6 kilometers).

All other groups have growth rates between 0 and 3\%. For all the ending nodes, we list two examples of countries with actual growth rates at the bottom of the tree. More detailed 
information on country-decades included in each ending node and their actual annual growth rates are presented in Online Appendix Tables 5 and 6.

We have also experimented with including FDI liability from Lane and Milesi-Ferretti (2007) instead of the stock of FDI measured by cumulative inflows in the prior three years at the beginning of each decade into the regression tree. However, it was not picked up by the tree as a robustly important variable either for the low-income group or the middle-income group ${ }^{21}$.

\section{For Middle-Income Countries}

We pool the lower-middle- and upper-middle-income countries together in the analysis. As shown in Figure 5, the important variables for explaining the growth performance of middle income countries include: demographics (share of population 15-64 years old and sex ratio of age 0-29), macroeconomic environment (government debt to GDP ratio, political constraints, and the number of crisis years in the decade), financial development (credit to private sector share), and initial income level.

Based on the growth performance, similar to the low-income group analysis, we categorize countries into three groups: progressive, near-stagnant, and regressive.

In the progressive group, countries with favorable demographics (share of population 15-64 years old higher than 58.5\%) and lower initial income (lower than \$5,437) can expect an annual growth rate as high as $6.9 \%$ when government debt share is lower than $31.8 \%$; or growth rate at $4.9 \%$ when government debt share is higher than $31.8 \%$. Countries with a higher initial income (higher than $\$ 5,437$ ), a sex ratio of the age cohort 0-29 greater than 1.03, and a lower government debt share (lower than $41.5 \%$ ) can expect to have a growth rate of $4.06 \%$; or if their government debt share is high (higher than $41.5 \%$ ), but possess very favorable demographics (share of population 15-64 years old higher than 64.4\%), they can achieve a growth rate of $4.08 \%$; while if the sex ratio is lower than 1.03, sound political constraints can still help to achieve a growth rate of $3.88 \%{ }^{22}$. A third group featuring less favorable demographics (share of population 15-64 years old lower than 58.5\%) but a low government debt ratio (lower than 55.9\%) and few crisis years (less than or equal to 1) can still expect an annual growth rate of $3.6 \%$.

Middle-income countries can also produce their version of regressive group. In particular, for a combination of unfavorable demographics (share of population 15-64 years lower than 58.5\%), relatively high government debt (greater than $55.9 \%$ of GDP), and poor financial development (domestic credit to private sector lower than $28.7 \%$ of GDP), growth becomes $-1.34 \%$ a year. Of course, since these countries become poorer over time, they are doing worse than being trapped in

\footnotetext{
21 The FDI liability data is from Lane and Milesi-Ferretti's paper (JIE, 2007), which is based on a estimation method. The FDI flow data is from Bluedorn et al.'s paper (IMF, 2013), which is based on BPS data. Both are supposed to cover 145/150 countries starting from 1970. However, the estimation method gives higher coverage data for liabilities.

22 In addition to political constraint index used by Henisz (2000, 2002), we also include three other measures of political systems into the analysis, including the frequency of government crisis, the number of changes in the government cabinet from CNTS, and absence of violence from WGI. We have experimented with both including them simultaneously or including them one at a time. None of them is regarded as robustly important by the regression tree for any of the three income groups.
} 
a middle-income trap. If their policy choices and fundamentals do not change, in principle, they can slip out of the middle-income group and become low-income countries again.

Countries with other characteristics are expected to have growth rates between 0 and $3 \%$. The anemic growth rates would leave these countries behind the existing high-income countries as a group in relative terms.

To summarize, these findings can be used to gauge empirical importance of various theories of economic growth. In particular, for countries in the middle-income group, those theories that stress a favorable demographic pattern (a high share of working age population) and prudent macro debt management are likely to be relevant. Without a favorable demographic pattern, a prudent macro debt management can still deliver strong growth. In contrast, macroeconomic instability in the form of high government debt and inadequate financial development are likely to lead to anemic or even negative growth rates.

Note that, in the previous analysis, the growth performance of high-income countries is taken as part of the global economic environment that could affect low- and middle-income countries. In Appendix Figure 2, we report a regression tree analysis of the growth correlates for high-income countries themselves ${ }^{23}$. We find that demographics (the sex ratio of cohort 0-29 and the share of labor-force-age population), degree of democracy, infrastructure, and the initial income level are especially important in separating relatively fast growing and slow growing economies.

\subsection{Robustness Check with Random Forest Analysis}

As a non-parametric technique, relative to a linear regression analysis, the regression tree analysis enjoys several advantages: no required transformation of variables, robustness to outliers, and greater tolerance of missing data without having to impute values. However, results of the regression tree analysis are potentially sensitive to changes in the sample (see Shmueli et al., 2007, page 132). To examine sensitivity to different subsamples, a random forest technique is proposed and used by Breiman (2001) and Hapfelmeier (2012). A random forest is a combination of many trees, with each constructed on the basis of an independently and randomly drawn sub-sample. Therefore, as the number of trees in the forest increases, the random errors are averaged out by taking the average of the trees. By construction, each tree is constructed on sub-sample, the forest does not include the full-sample tree itself.

For each income group, we will grow a forest with 1000 trees $^{24}$ (based on 1000 randomly drawn sub-samples). In defining the parameters to grow the trees, we employ the unbiased random forest suggested by Strobl et al. (2007). ${ }^{25}$ For each tree, we require the maximum p-value for a split to be $5 \%$, the minimum size for a split to be 20 , the minimum size for the ending node to be 8 , and the re-sample size of $90 \%$ as in the baseline case of the full sample.

\footnotetext{
${ }^{23}$ We exclude the global growth indicator in this case.

24 The function of cforest in the package of party in $\mathrm{R}$ is employed.

25 With teststat="quad", testtype="Univariate" defined in the cforest_control.
} 
Unlike a regression tree, the results of a random forest are harder to visualize and are instead summarized in Online Appendix Table 2. The second column lists all the factors regarded as potentially important by the random forest technique, in descending order of the values in column 3. The frequency indicator in Column 3 refers to total number of appearances of a variable on all 1000 trees in the forest. (Note that a given variable can appear more than once on a tree as illustrated by the share of age cohort 15-64 in Figure 4.) Column 4 reports the average split value of the corresponding variables. For example, the share of age cohort 15-64 years old in population appears 1089 times in the forest for low income group and the average of its split value across all its appearances is $53.29 \%$. As illustrated in the regression tree analysis, for each split, those observations with values higher than the split value appear on the branch on the right, while those with lower values are on the left branch. Column 5 lists the average difference of the decade growth rates between observations on the right branch and those on the left branch when the corresponding variable at a given split. Therefore, if the difference is a positive number, the variable used for the split has a positive association with the growth rate. Using the share of population 15-64 years old as an example, we can say that on average, countries with a share higher than $53.29 \%$ has an annual growth rate around $1.76 \%$ higher than that of countries with a share lower than $53.29 \%$. The last column is a statistic that we construct to indicate the significance of the results in column 5. They are the frequencies of positive differences against the frequencies of negative differences. We generally would have a higher level of confidence the importance of a variable when the difference in the frequencies between the positive and negative contributions is large in absolute values.

We highlight all variables with a total frequency of 500 (out of 1000) or higher. For low-income countries, the share of population 15-64 years old, sex ratio of age 0-29, paved roads, power generating capacity, population growth of 15-64 years old, years of schooling, initial income, global growth, economic freedom, accumulated FDI inflows, and inflation, are the important variables. The variables shown in the regression tree for the whole sample such as favorable demographics, good infrastructure, and sound macroeconomic environment are all picked up as important variables by the forest, which suggests robustness of these variables.

The difference between the right and left branches of each split in the regression tree is conditional on the unique tree structure that was constructed based on the whole sample. By contrast, the contribution of each variable (column 5 in Appendix Table 2) in a forest is the average of the contributions of all splits using that variable conditional on the tree structures across the forest. Conditional on the tree structures in the forest, we consider their contribution in the forest as the "marginal" effect of that variable on growth. The regression tree and the random forest can be used for different purposes. For "diagnostic" purpose, such as determining what institutional/fundamental combination can help one economy improve its growth (moving from the regressive group to the progressive group), the regression tree is better. For prioritization purposes, the forest is better since it ranks the importance (marginal effect) of each variable.

In our analysis, although the structure of the regression tree is potentially sensitive to changes in the sample, the resulting country groupings in the end nodes are quite stable. Our intuition is that when the factors are close competitors in explaining the growth differentiation 
between groups (making the splits), the structure of the tree is more sensitive to data changes. For example, when factor A and factor B are equally good in doing the split, either A or B can be chosen to do the split. While the structure of the tree would be different (since one tree would have factor A and the other tree would have factor B), the country groupings in the end nodes would be exactly the same. This may imply a change in perspective in the application of the regression tree. That is, as long as factor A can represent factor B (or vice versa), it does not matter much which one is on the tree to do the split. For example, the years of schooling is a competing factor of sex ratio of age $0-29$, however, as shown in the regression tree analysis, sex ratio of age 0-29 outperforms the years of schooling in explaining the growth.

For middle-income countries, variables with frequencies higher than 500 include the share of population 15-64 years old, the years of banking or currency crises in a decade, government debt share, initial income, inflation, sex ratio of age 0-29, years of schooling, credit to deposit ratio, political constraints, conflicts index, checks and balance (existence of veto players), global growth rate, and the number of conflicts. Again, the variables picked up by the forest encompass most variables shown in the regression tree, which suggests that our regression tree results are robust.

\section{Conclusion: Linking the Conditional and Unconditional Analyses}

In this paper, we examine the growth performance of countries at different income status. In the first half of the paper, we reject the unconditional notion of a "middle-income trap," or a "low-income trap." That is, an average country in either the low- or middle-income group has a more than $50 \%$ chance of having a positive growth rate. Therefore, given enough time, an average country is always expected to move to a higher income status. The only trap in the data is a high-income trap in the sense that once a country enters the high-income club, it is always expected to stay there.

On the other hand, in terms of incomes relative to the contemporaneous leader, there is no full convergence. That is, if we iterate historic growth record, then there are always countries whose incomes fall short of the leader even in the long run. It is important note, however, the transition probability for moving to the next higher income group is no lower for middle income countries than for low income countries. Countries in every income group face some challenges to grow fast; there is no compelling evidence to state that middle income countries face the roughest odd.

In the second half of the paper, we find that a relatively succinct list of variables can separate fast-growing and slow-growing economies in any given income group.

We now link the conditional results based on the regression trees to the unconditional results based on transition matrices. We divide the countries into five groups: extremely low-income, low-income, lower-middle-income, upper-middle-income, and high-income countries using the same criteria as the unconditional transition matrix in Section 2. In each group, we have three types of countries: progressive (with an expected annual growth rate higher than $3 \%$ based on the regression tree), near-stagnant (with an annual growth rate between 0 and 3\%), and regressive (with a negative annual growth rate). The results are presented in Table 5. 
Conditional on the sample and the regression tree results, we show that for extremely low-income groups, 20 out of 92 country-decades belong to progressive countries, and they have a $75 \%$ probability of moving up to the next higher-income group-i.e., the low-income group - within one decade. It only takes 5 years for half of them to move up to the next higher-income group or 17 years for $90 \%$ of them to move up. For these countries, there is clearly no low-income trap. For the near-stagnant countries (57 out of 92), the scenario is much worse; the upward decade transition probability is only $12 \%$. It will take 53 years (176 years) for $50 \%$ $(90 \%)$ of them to move up to higher-income groups. For the regressive group (15 out of 92), i.e., those with negative growth rates, they will never move up to higher-income groups if nothing else changes. With policy choices and fundamentals that characterize the regressive group of low-income countries (i.e., high inflation and unfavorable demographics), these countries are likely trapped in poverty.

We perform a similar exercise for the other three income groups. In general, there is no trap for countries in a progressive group. They are expected to move to the next income group within a relatively short period of time. For countries in a regressive group, the negative expected growth rate implies that they may do worse than being simply trapped in their current income status. For countries in a near-stagnant group, because growth is low, they may look like they are being trapped in their current income status for a long time. One interesting observation is that even for the progressive countries, it takes longer for the upper-middle-income countries to move up compared with the other income groups since the income interval covered by the upper-middle-income group is much wider than the other groups. For example, it takes 38 years for $90 \%$ of the upper-middle-income countries to join the high-income club, but only 25 years for $90 \%$ of the lower-middle-income countries to move up, and 23 years for $90 \%$ of the low-income countries to move up. (In other words, part of the differences in the time it takes to move up are due to the income thresholds one chooses for the income groups.)

Based on what characterizes a progressive group in a given income group, one can also infer the types of changes in policies (and fundamentals) that might help hasten the pace of progress towards high-income status. As noted earlier, the regression tree method identifies plausible growth correlates (in a setting that allows for various non-linear interactions). With this list of growth correlates, additional research is needed to identify causal drivers for growth for countries in a given income group. For a given country, comparing its own policy regimes and fundamentals to these growth drivers provide hints for plausible priority reform items. 


\section{References}

Acemoglu, D., S. Johnson, and J. A. Robinson. 2001. "The Colonial Origins of Comparative Development: An Empirical Investigation.” American Economic Review 91(5): 1369-1401.

Acemoglu, D., S. Johnson, and J. A. Robinson. 2002. "Reversal of Fortune: Geography and Development in the Making of the Modern World Income Distribution." Quarterly Journal of Economics 117(4): 1231-1294.

Agénor , P.R., Canuto, O. ve Jelenic, M. (2012), “Avoiding Middle-Income Growth Traps”, The World Bank Working Paper, 98, Poverty Reduction and Economic Managament Network (PREM), Economic Premise, Washington DC.

Aiyar, S., R. Duval, D. Puy, Y. Wu, and L. Zhang. 2013. "Growth Slowdowns and the Middle-Income Trap.” IMF Working Paper. No. 13/71. Washington, DC.

Aisen, A. and Veiga, F.J. (2013), "How does political instability affect economic growth?" European Journal of Political Economy 29, 151-167.

Alesina, A., S. Ozler, N. Roubini, and P. Swagel. 1996. "Political instability and economic growth.” Journal of Economic Growth 1(2): 189-211.

Alfaro, L., C. Areendam, S. Kalemli-Ozcan, and S. Selin. 2003. "FDI and Economic Growth: The Role of Local Financial Markets.” Journal of International Economics 61(1): 512-533.

Athey, S., and G. Imbens, 2015, "Machine Learning Methods for Estimating Heterogeneous Causal Effects.” Working Paper, Stanford University

Balasubramanyam, V. N., M. Salisu, and D. Sapsford. 1996. "Foreign Direct Investment and Growth in EP and IS Countries.” Economic Journal 106(434): 92-105.

Barro, R. J. 1991. Economic Growth in a Cross-Section of Countries. Quarterly Journal of Economics 106(2): 407-443.

Barro, R. J. 2000. Inequality and Growth in a Panel of Countries. Journal of Economic Growth 5(1): 5-32.

Barro, R. J. and X. Sala-i-Martin. 2004. Economic Growth. Cambridge, MA: The MIT Press.

Beck, T., Clarke, G., Groff, A., Keefer, P., Walsh, P. (2001). "New tools in comparative political economy: the database of political institutions." World Bank Economic Review 15, $165-176$.

Benhabib, J. and M. Spiegel. 1994. "The Role of Human Capital in Economic Development: Evidence from Aggregate Cross-Country Data.” Journal of Monetary Economics 34(2): $143-173$. 
Benhabib, J. and M. Spiegel. 2005. "Human Capital and Technology Diffusion", ch. 13, p. 935-966 in Aghion, Philippe and Durlauf, Steven eds., Handbook of Economic Growth, vol. 1, Part A, Elsevier.

Bloom, D. E., D. Canning, G. Fink, and J. E. Finlay. 2007. "Does Age Structure Forecast Economic Growth?" International Journal of Forecasting 23(4): 569-585.

Bloom, D. E., D. Canning, and P. Malaney. 2000. "Demographic Change and Economic Growth in Asia." Population and Development Review 26(Supplement): 257-290.

Bloom, D. E., D. Canning, and J. Sevilla. 2003. "The Demographic Dividend: A New Perspective on the Economic Consequences of Population Change.” Population Matters Monograph MR-1274. RAND. Santa Monica.

Bluedorn, J., R. Duttagupta, J. Guajardo, and P. Topalova. 2013. "Capital Flows are Fickle: Anytime, Anywhere.” IMF Working Paper No. WP/13/183. International Monetary Fund. Washington, DC.

Borensztein, E., J. De Gregorio, and J.-W. Lee. 1998. "How does Foregin Investment Affect Growth?” Journal of International Economics 45(1): 115-172.

Breiman, L. 2001. "Random Forests.” Machine Learning 45(1): 5-32.

Breiman, L., J. Friedman, R. Ohlsen, and C. Stone. 1984. Classification and Regression Trees. Belmont, CA: Wadsworth.

Bulman, D., M. Eden, and H. Nguyen. 2014. "Transitioning from Low-Income Growth to High-Income Growth: Is there a Middle-income Trap?” WB Policy Rearch Working Paper No. 7104. World Bank. Washington, DC.

Calderón, C., E. Moral-Benito, and L. Servén. 2014. "Is Infrastructure Capital Productive? A Dynamic Heterogeneous Approach.” Journal of Applied Econometrics 30(2): 177-198.

Caselli, F. and A. Ciccone. 2013. "The Contribution of Schooling in Development Accounting: Results from a Nonparametric Upper Bound." Journal of Development Economics 104(C): 199-211.

Čihák, M., A. Demirgüç-Kunt, E. Feyen, and R. Levine. 2013. "Financial Development in 205 Economies, 1960 to 2010.” Journal of Financial Perspectives 1(2): 17-36.

Deininger, K. and L. Squire. 1998. "New Ways of Looking at Old Issues: Inequality and Growth." Journal of Development Economics 57(2): 259-287.

Demirgüç-Kunt, A., and R. Levine. 2008. "Finance, Financial Sector Policies, and Long Run Growth." M. Spence Growth Commission Background Paper No. 11. World Bank. Washington, DC.

Dollar, D. and A. Kraay. 2003. "Institutions, Trade and Growth.” Journal of Monetary Economics 50(1): 133-162. 
Du, Q. and S.-J. Wei. 2013. "A Theory of the Competitive Saving Motive." Journal of International Economics 91(2): 275-289.

Durlauf, S. N. and P. A. Johnson. 1995. "Multiple Regimes and Cross-Country Growth Behavior." Journal of Applied Econometrics 10(4): 365-384.

Easterly, W. and R. Levine. 2003. "Tropics, Germs, and Crops: How Endowments Influence Economic Development.” Journal of Monetary Economics 50(1): 3-39.

Egert, B., T. Kozluk, and D. Sutherland. 2009. "Infrastructure and Growth: Empirical Evidence." William Davidson Institute Working Paper 957, University of Michigan. Ann Arbor.

Eichengreen, B., D. Park and K. Shin. 2012. "When Fast Growing Economies Slow Down: International Evidence and Implications for China”, Asian Economic Papers, 11, 42-87.

Eichengreen, B., D. Park, and K. Shin. 2013. "Growth Slowdowns Redux: New Evidence on the Middle-Income Trap.” NBER Working Paper. No. 18673.

Felipe, J., U. Kumar, and R. Galope. 2014. "Middle-Income Transition: Trap or Myth?” ADB Economics Working Paper No. 421. Asian Development Bank. Manila.

Felipe, J., A. Mahta, and C. Rhee. 2014. "Manufacturing Matters... but It's the Jobs That Count" ADB Economics Working Paper No. 420. Asian Development Bank. Manila.

Feyrer, J. 2009. “Trade and Income - Exploiting Time Series in Geography.” NBER Working Paper No. 14910. National Bureau of Economic Research. Cambridge, MA.

Frankel, J. and D. Romer. 1999. “Does Trade Cause Growth?” American Economic Review 89(3): 379-399.

Forbes, K. 2000. "A Reassessment of the Relationship Between Inequality and Growth." American Economic Review 90(4): 869-887.

Forbes, K. and F. Warnock. 2012. "Capital Flow Waves: Surges, Stops, Flight, and Retrenchment." Journal of International Economics 88(2): 235-251.

Galor, Oded. and J. Zeira. 1993. "Income Distribution and Macroeconomics." Review of Economic Studies 60(1): 35-52.

Gill, I. and H. Kharas. 2007. “An East Asian Renaissance: Ideas for Economic Growth”, World Bank, Washington, DC

Gill, I. S., and H. Kharas. 2015. “The Middle-Income Trap Turns Ten.” Policy Research Working Paper 7403. World Bank, Washington, DC.

Glaeser, E. L., R. La Porta, F. Lopez-de-Silanes, and A. Shleifer. 2004. "Do Institutions Cause Growth?" Journal of Economic Growth 9(3): 271-303.

Gwartney, J., Lawson, R., and Hall, J. 2015. Economic Freedom of the World 2015 Annual Report, Fraser Institute, Vancouver, B.C. 
Hall, R. E. and C. I. Jones. 1999. "Why Do Some Countries Produce so Much More Output per Worker than Others?" The Quarterly Journal of Economics 114(1): 83-116.

Hanushek, E. A. and L. Woessmann. 2008. "The Role of Cognitive Skills in Economic Development.” Journal of Economic Literature 46(3): 607-668.

Hapfelmeier, A. 2012. "Analysis of Missing Data with Random Forests." PhD. Dissertation. Ludwig-Maximilians-Universität. München.

Henisz, W. J. 2000. "The Institutional Environment for Economic Growth." Economics and Politics 12(1): 1-31.

Henisz, W. J. 2002. "The Institutional Environment for Infrastructure Investment." Industrial and Corporate Change 11(2): 355-389.

Hothorn, T., K. Hornik, and A. Zeileis. 2006. "Unbiased Recursive Partitioning: A Conditional Inference Framework.” Journal of Computational and Graphical Statistics 15(3): $651-674$.

Im, F. G. and D. Rosenblatt. 2013. "Middle-Income Traps: A Conceptual and Empiral Survey." WB Policy Research Working Paper No. 6594. The World Bank. Washington, DC.

International Monetary Fund. 2014. "Is It Time for An Infrastructure Push? The Macroeconomic Effects of Public Investment," Chapter 3 in World Economic Outlook 2014. Washington, DC.

Jones, C. 2015. “The Facts of Economic Growth.” NBER Working Paper No. 21142.

Jong-a-Pin, R. 2009. "On the measurement of political instability and its impact on economic growth." European Journal of Political Economy 25, 15-29.

Kremer, Michael, Alexei Onatski and James Stock. 2001. "Searching for Prosperity." Carnegie-Rochester Conference Series on Public Policy 55(December): 275-303.

Lane, P., Milesi-Ferretti, G.M. 2007. "The external wealth of nations mark II: revised and extended estimates of foreign assets and liabilities, 1970-2004." Journal of International Economics $73,223-250$.

Levine, R. 2005. "Finance and Growth: Theory and Evidence." In Philippe Aghion and Steven Durlauf (eds.), Handbook of Economic Growth, volume 1, chapter 12, pp. 865-934.

Mankiw, G., D. Romer, and D. Weil. 1992. "A Contribution to the Empirics of Growth." Quarterly Journal of Economics 107(2): 407-437.

Nakao, T. 2014. “An Eight-Point Development Agenda for Sustainable Growth in Asia." Keynote address at the 5th Asian Development Forum, 19 September, Ha Noi, Viet Nam.

Ohno, Kenichi. 2009. "Avoiding the Middle-Income Trap: Renovating Industrial Policy Formulation in Vietnam" ASEAN Economic Bulletin 26: 25-43. 
Pritchett, L. and L. H. Summers. 2014. "Asiaphoria Meets Regression to the Mean.” NBER Working Paper No. 20573. National Bureau of Economic Research. Cambridge, MA.

Quah, Danny. 1996a. "Twin Peaks" Growth and Convergence in Models of Distribution Dynamics.” Economic Journal 106(437): 1015-55.

Quah, Danny. 1996b. "Convergence Empirics across Economies with (Some) Capital Mobility." Journal of Economic Growth 1(1): 95-124.

Reinhart, C. M. and K. S. Rogoff. 2009. This Time is Different: Eight Centuries of Financial Folly. Princeton: Princeton University Press.

Robertson, P. E. and L. Ye. 2013. "On the Existence of a Middle-income Trap." Economics Discussion Paper No. 13.12. University of Western Australia. Perth.

Rodrik, Dani. 2015. "Premature Deindustrialization" Journal of Economic Growth 21: 1-33.

Rodriguez, F. and D. Rodrik. 2001. "Trade Policy and Economic Growth: A Skeptic's Guide to the Cross-National Evidence." NBER Macroeconomics Annual 2000 15: 261-338.

Rodrik, D., A. Subramanian, and F. Trebbi. 2002. "Institutions Rule: The Primacy of Institutions over Geography and Integration in Economic Development." Journal of Economic Growth 9(2): 131-165.Rudengren, T., L. Rylander, and C. R. Casanova. 2014. "It's Democracy, Stupid: Reappraising the Middle-Income Trap." Institute for Security and Development Policy. Stockholm-Nacka.

Shmueli, G., N. R. Patel, and P. C. Bruce. 2007. Data Mining for Business Intelligence: Concepts, Techniques, and Applications in Microsoft Office Excel with XLMiner. New Jersey: Wiley-Interscience.

Strasser, H. and C. Weber. 1999. "On the Asymptotic Theory of Permutation Statistics." Mathematical Methods of Statistics 8: 220-250.

Straub, S. 2008. "Infrastructure and Growth in Developing Countries: Recent Advances and Research Challenges.” WB Working Paper No. 4460. World Bank. Washington, DC.

Strobl, C., A. L. Boulesteix, A. Zelieis, and T. Hothorn. 2007. "Bias in Random Forest Variable Importance Measures: Illustrations, Sources and a Solution." BMC Bioinformatics 8(1): 25 .

Wei, S-J. and X. Zhang. 2011a. "The Competitive Saving Motive: Evidence from Rising Sex Ratios and Saving Rates in China." Journal of Political Economy 119(3): 511-564.

Wei, S-J. and X. Zhang. 2011b. "Sex Ratio, Entrepreneurship, and Economic Growth in the People's Republic of China." NBER Working Paper No. 16800.

Wei, S-J. and X. Zhang. 2012. "Status Competition and Housing Prices" NBER Working Paper No. 18000. National Bureau of Economic Research. Cambridge, MA. 
World Bank. 2013. The World Bank Group Goals: End Extreme Poverty and Promote Shared Prosperity. Washington, DC. Available: www.worldbank.org.

Woo, W. 2009. Getting Malaysia Out of the Middle-Income Trap. Working Paper. University of California,Davis. http://faculty.econ.ucdavis.edu/faculty/woo/SEA\%20for\%20webpage/Wing\%20Woo.Ma laysia\%20Out\%20of\%20Middle-Income\%20Trap.pdf 
Table 1. Decade-average transition matrix for 1960-2010 (in \%)

\begin{tabular}{lccccc}
\hline Extremely & $\begin{array}{c}\text { Low- } \\
\text { Income }\end{array}$ & $\begin{array}{c}\text { Lower- } \\
\text { Middle- } \\
\text { Income }\end{array}$ & $\begin{array}{c}\text { Upper- } \\
\text { Middle- } \\
\text { Income }\end{array}$ & $\begin{array}{c}\text { High- } \\
\text { Income }\end{array}$ \\
\hline ELI & 82 & 18 & 0 & 0 & 0 \\
LI & 3 & 72 & 25 & 0 & 0 \\
LMI & 0 & 3 & 68 & 29 & 0 \\
UMI & 0 & 0 & 0 & 70 & 30 \\
HI & 0 & 0 & 0 & 0 & 100 \\
\hline
\end{tabular}

Ergodic distribution for the average decade transition matrix

$\begin{array}{lrrrr}0 & 0 & 0 & 0 & 100\end{array}$

ELI = extremely low-income; $\mathrm{HI}$ = high-income; $\mathrm{LI}=$ low-income; $\mathrm{LMI}=$ lower-middle-income; UMI = upper-middle-income

Table 2. Decades needed for X percent of countries to move up and out of their current group

\begin{tabular}{ccccc}
\hline & $\begin{array}{c}\text { Extremely } \\
\text { Low- } \\
\text { Income }\end{array}$ & $\begin{array}{c}\text { Low- } \\
\text { Income }\end{array}$ & $\begin{array}{c}\text { Lower- } \\
\text { Middle- } \\
\text { Income }\end{array}$ & $\begin{array}{c}\text { Upper- } \\
\text { Middle- } \\
\text { Income }\end{array}$ \\
\hline $\mathrm{X}=0.5$ & 4 & 3 & 3 & 2 \\
$\mathrm{X}=0.9$ & 14 & 12 & 8 & 7 \\
\hline
\end{tabular}

Table 3. Decade-average transition matrix for 1960-2010 relative to US (in \%)

\begin{tabular}{lcccc}
\hline & $\begin{array}{c}16 \% \text { and Below } \\
\text { (Extremely Low } \\
\text { and Low) }\end{array}$ & $\begin{array}{c}16 \%-36 \% \\
\text { (Lower-Middle) }\end{array}$ & $\begin{array}{c}36 \%-75 \% \\
\text { (Upper-Middle) }\end{array}$ & $\begin{array}{c}75 \% \text { and } \\
\text { above } \\
\text { (High) }\end{array}$ \\
\hline $16 \%$ and Below (LI) & 92 & 8 & 0 & 0 \\
$16 \%-36 \%$ (LMI) & 13 & 72 & 15 & 0 \\
$36 \%-75 \%$ (UMI) & 0 & 4 & 74 & 22 \\
$75 \%$ and above (HI) & 0 & 2 & 19 & 79 \\
\hline Ergodic distribution associated with transition matrices relative to US & 33 \\
\hline \multicolumn{5}{l}{} \\
\hline
\end{tabular}

$\mathrm{HI}=$ high-income; $\mathrm{LI}=$ low-income; $\mathrm{LMI}=$ lower-middle-income; $\mathrm{UMI}=$ upper-middle-income 
Table 4. Transition matrix based on Maddison data (in \%)

\begin{tabular}{|c|c|c|c|c|}
\hline \multicolumn{5}{|c|}{ (in 1990 International Geary-Khamis dollars) } \\
\hline & Low & Lower-Middle & Upper-Middle & High \\
\hline & $\$ 1-\$ 1,812$ & $\$ 1,813-\$ 4,078$ & $\$ 4,079-\$ 11,327$ & $\$ 11,328$ and above \\
\hline \multicolumn{5}{|l|}{$1850-1900$} \\
\hline Low & 52 & 39 & 9 & 0 \\
\hline Lower-middle & 0 & 75 & 25 & 0 \\
\hline Upper-middle & - & - & - & - \\
\hline High & - & - & - & - \\
\hline \multicolumn{5}{|l|}{$1900-1950$} \\
\hline Low & 41 & 50 & 9 & 0 \\
\hline Lower-middle & 0 & 21 & 79 & 0 \\
\hline Upper-middle & 0 & 0 & 100 & 0 \\
\hline High & - & - & - & - \\
\hline \multicolumn{5}{|l|}{ 1950-2000 } \\
\hline Low & 59 & 24 & 15 & 2 \\
\hline Lower-middle & 0 & 26 & 37 & 37 \\
\hline Upper-middle & 0 & 0 & 19 & 81 \\
\hline High & 0 & 0 & 0 & 100 \\
\hline \multicolumn{5}{|c|}{ Ergodic Distribution based on transition matrix of $1950-2000$} \\
\hline & 0 & 0 & 0 & 100 \\
\hline
\end{tabular}


Table 5. Regression-Tree-Simulated Transition Matrix (in \%)

\begin{tabular}{|c|c|c|c|c|c|c|c|c|c|}
\hline & $\begin{array}{l}\text { obs. in the group } \\
\text { / total obs. }\end{array}$ & $\begin{array}{c}\text { obs. } \\
\text { percentage }\end{array}$ & $\begin{array}{c}\text { Extremely } \\
\text { Low- } \\
\text { Income }\end{array}$ & $\begin{array}{l}\text { Low- } \\
\text { Income }\end{array}$ & $\begin{array}{l}\text { Lower-Middle } \\
\text {-Income }\end{array}$ & $\begin{array}{l}\text { Upper-Middle } \\
\text {-Income }\end{array}$ & $\begin{array}{l}\text { High- } \\
\text { Income }\end{array}$ & $\begin{array}{c}\text { \# years for } \\
50 \% \text { moving } \\
\text { up }\end{array}$ & $\begin{array}{c}\text { \# years for } 90 \% \\
\text { moving up }\end{array}$ \\
\hline \multicolumn{10}{|c|}{ Extremely Low-Income Countries } \\
\hline Progressive & $20 / 92$ & 0.22 & 25 & 75 & 0 & 0 & 0 & 5 & 17 \\
\hline Near-stagnant & $57 / 92$ & 0.62 & 88 & 12 & 0 & 0 & 0 & 53 & 176 \\
\hline Regressive & $15 / 92$ & 0.16 & 100 & 0 & 0 & 0 & 0 & never & never \\
\hline \multicolumn{10}{|c|}{ Low-Income Countries } \\
\hline Progressive & $44 / 112$ & 0.39 & 0 & 36 & 64 & 0 & 0 & 7 & 23 \\
\hline Near-stagnant & $47 / 112$ & 0.42 & 0 & 96 & 4 & 0 & 0 & 160 & 530 \\
\hline Regressive & $21 / 112$ & 0.19 & 14 & 86 & 0 & 0 & 0 & never & never \\
\hline \multicolumn{10}{|c|}{ Lower-Middle-Income Countries } \\
\hline Progressive & $46 / 92$ & 0.5 & 0 & 0 & 39 & 61 & 0 & 8 & 25 \\
\hline Near-stagnant & $37 / 92$ & 0.4 & 0 & 0 & 89 & 11 & 0 & 61 & 202 \\
\hline Regressive & 9/92 & 0.1 & 0 & 22 & 78 & 0 & 0 & never & never \\
\hline \multicolumn{10}{|c|}{ Upper-Middle-Income Countries } \\
\hline Progressive & $50 / 114$ & 0.44 & 0 & 0 & 0 & 54 & 46 & 12 & 38 \\
\hline Near-stagnant & $62 / 114$ & 0.54 & 0 & 0 & 0 & 81 & 19 & 33 & 108 \\
\hline Regressive & $2 / 114$ & 0.02 & 0 & 0 & 0 & 100 & 0 & never & never \\
\hline
\end{tabular}


Figure 1. Income Transition from 1960 to $2011^{26}$

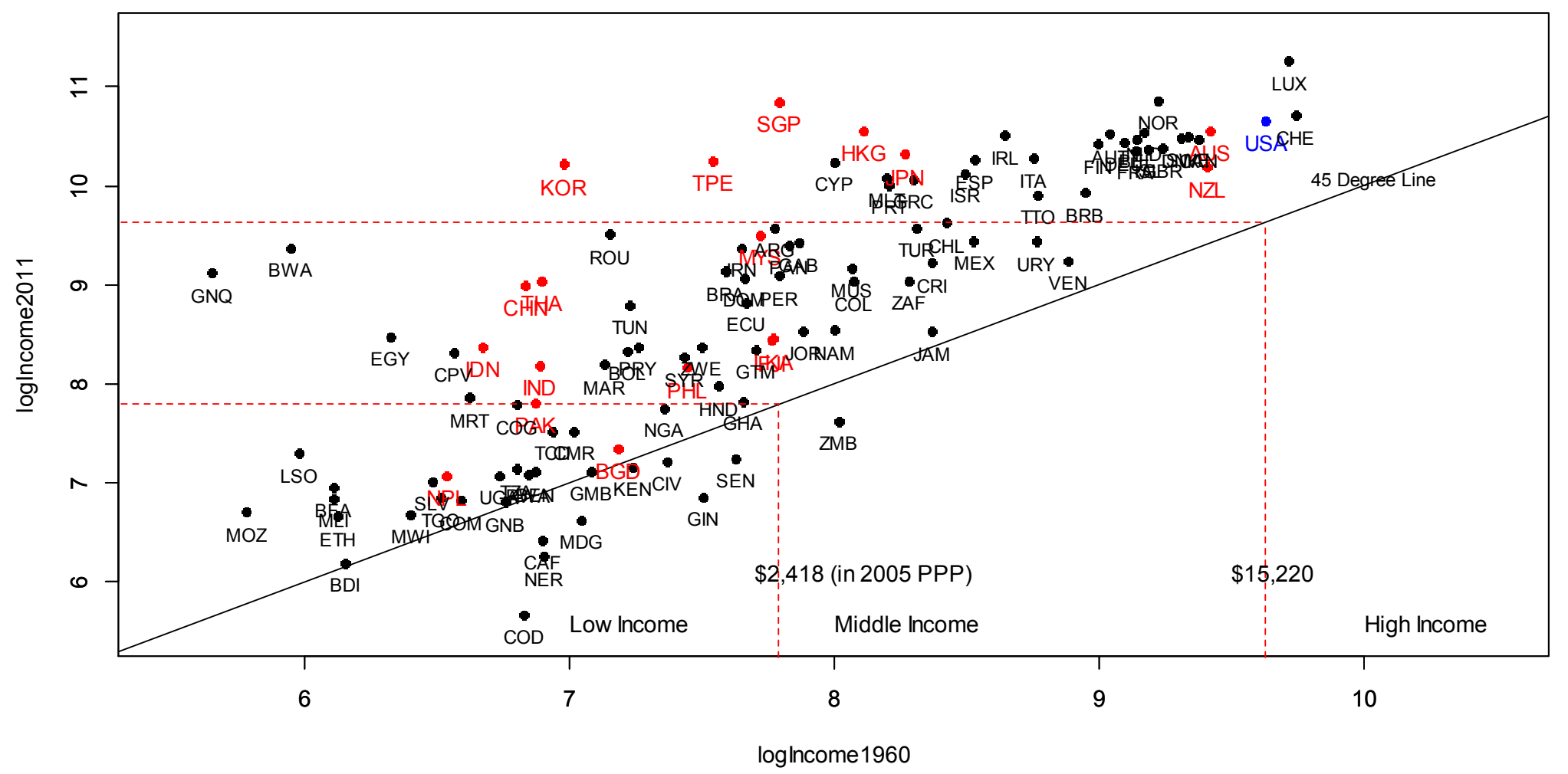

${ }^{26}$ Some Central Asian countries are missing because of data unavailability. 
Figure 2. Income Transition from 1960 to 2011 in relative terms to the US

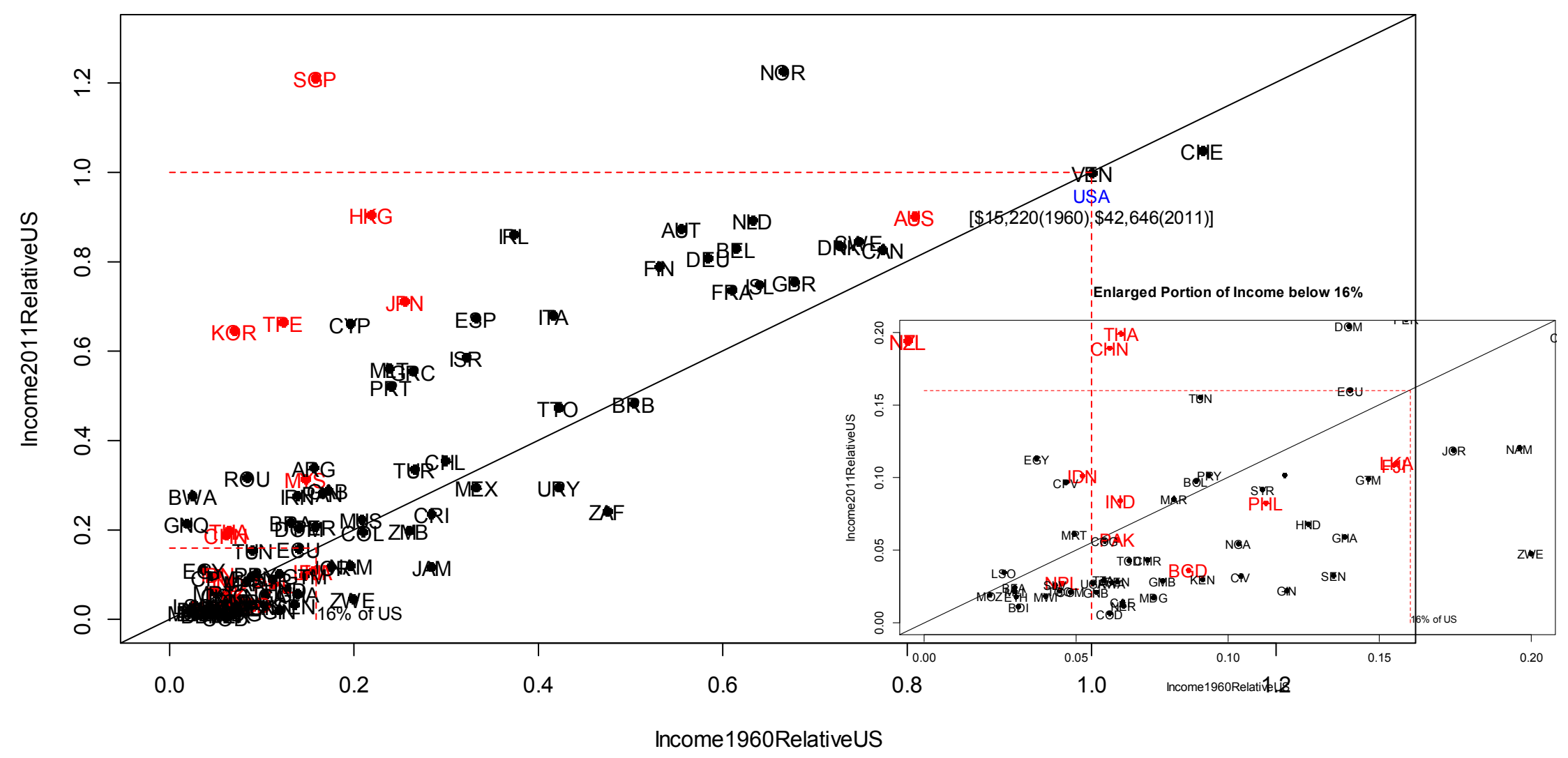


Figure 3 Growth Rates and Initial Income in 1960, 1980, and 2000

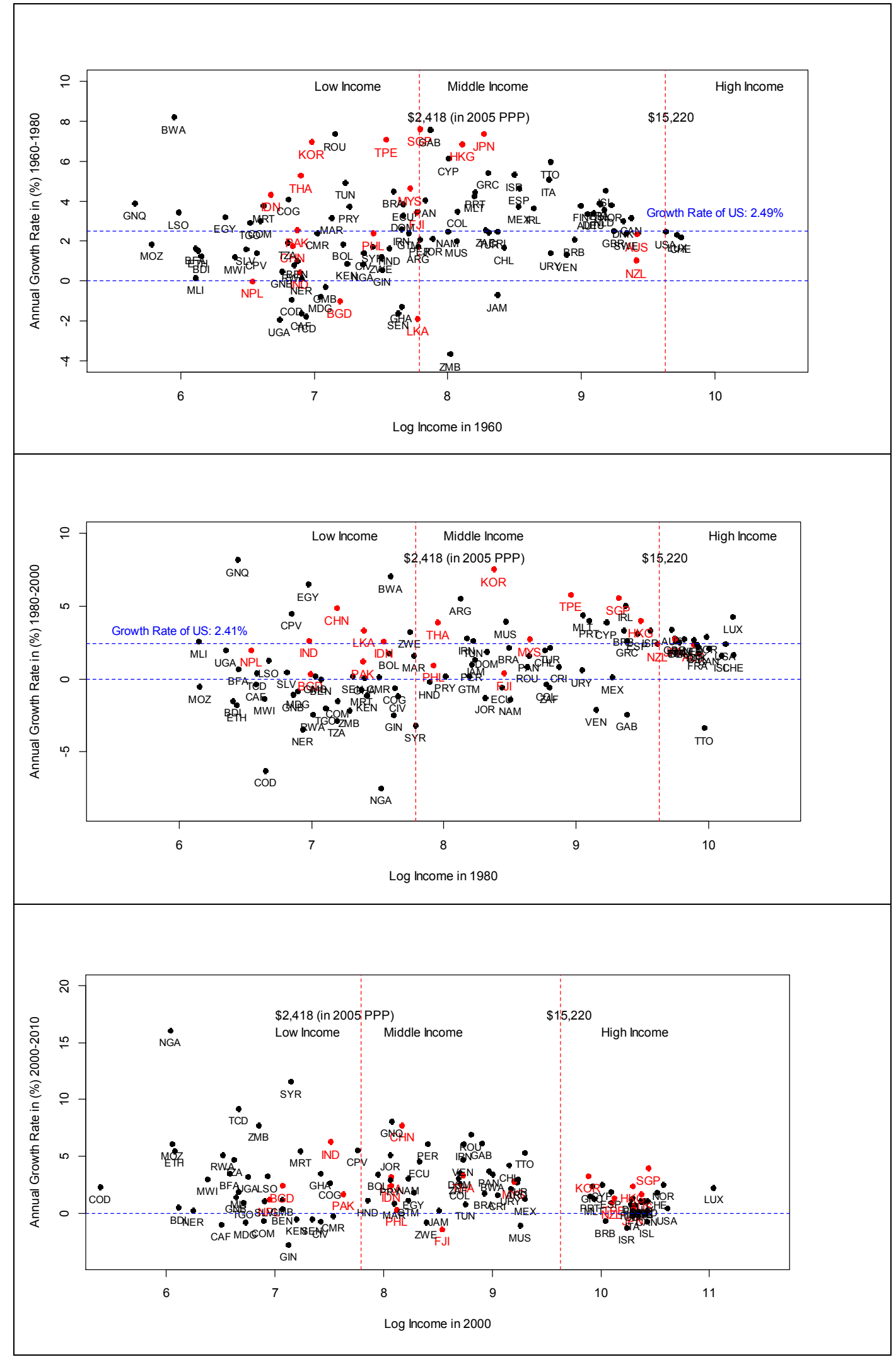


Figure 4. Growth Correlates for Low-Income Countries

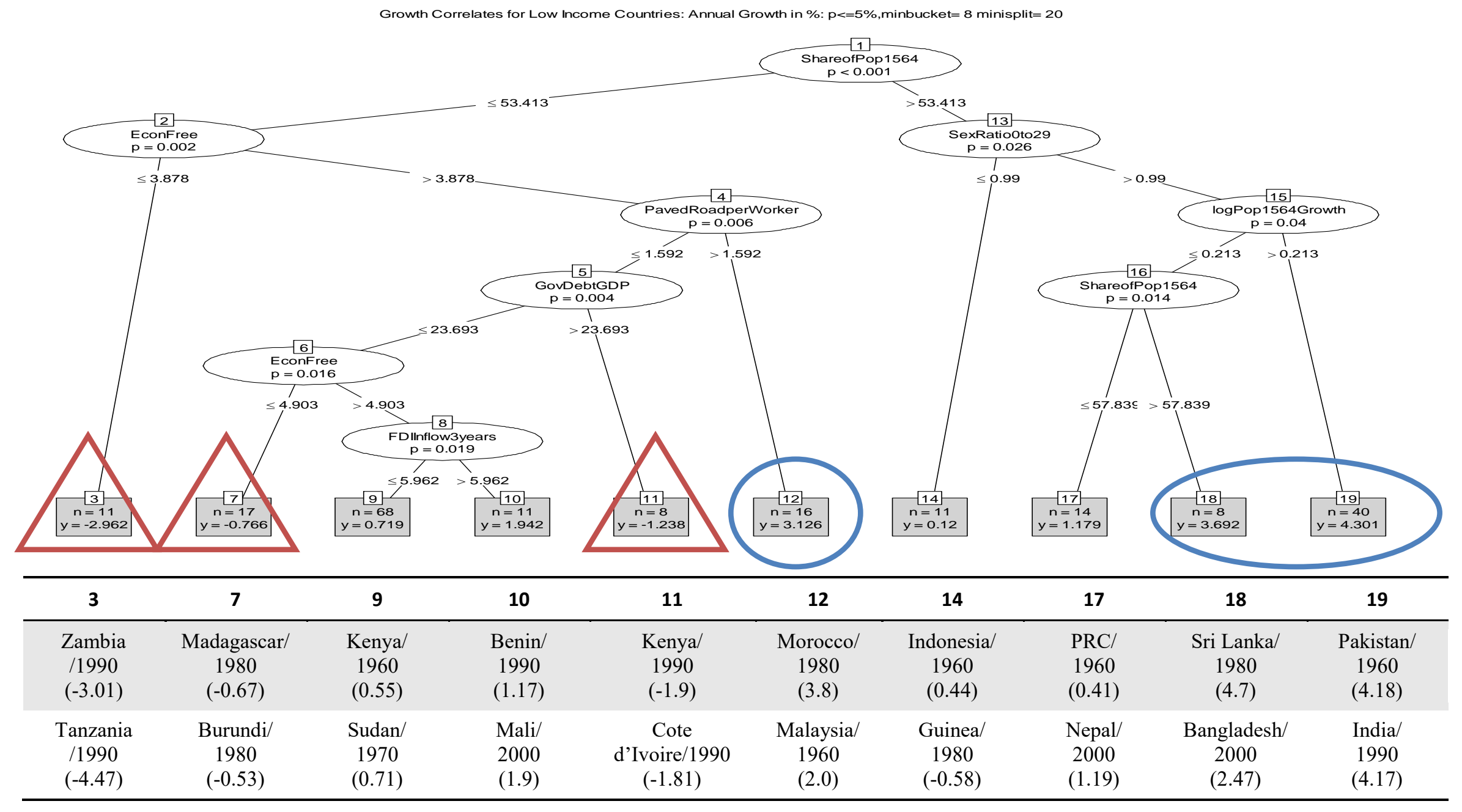


Figure 5. Growth Correlates for Middle-Income Countries

Growth Correlates for Middle Income Countries: Annual Growth in \%: $p<=5 \%$, minbucket $=8$ minisplit= 20

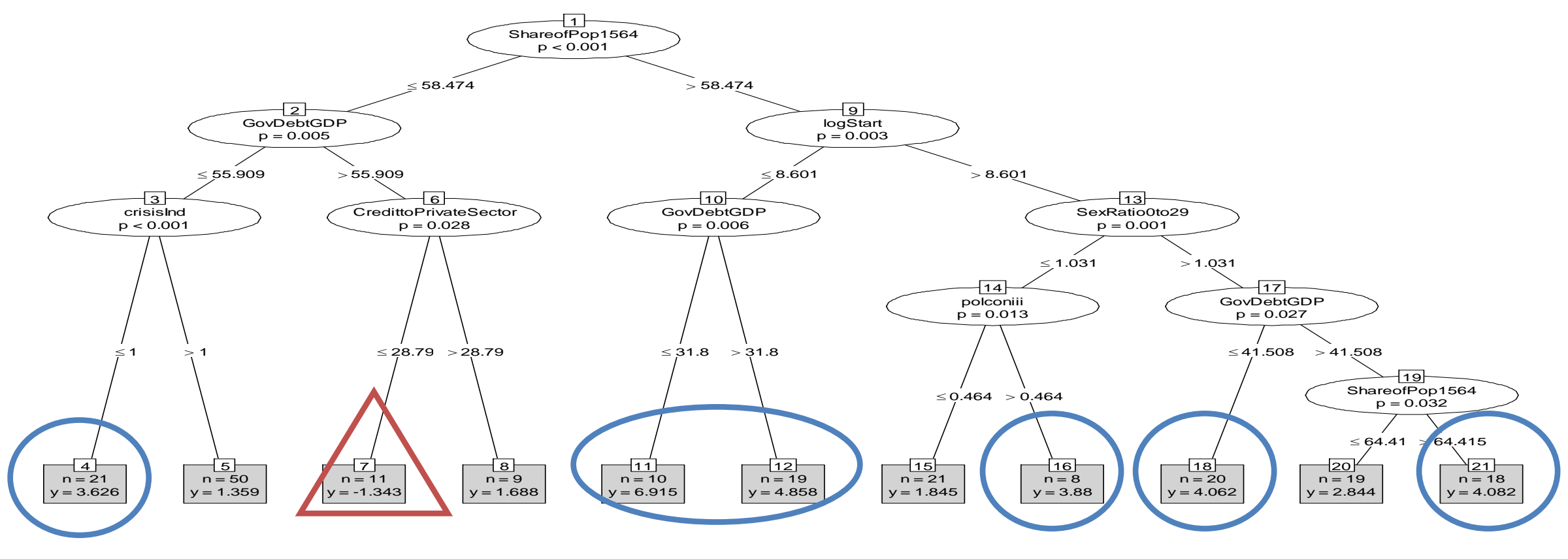

\begin{tabular}{|c|c|c|c|c|c|c|c|c|c|c|}
\hline 4 & 5 & 7 & 8 & 11 & 12 & 15 & 16 & 18 & 20 & 21 \\
\hline $\begin{array}{c}\text { Turkey } \\
/ 1960 \\
(3.52)\end{array}$ & $\begin{array}{c}\text { Philippines } \\
/ 1980 \\
(1.15)\end{array}$ & $\begin{array}{c}\text { Sri Lanka } \\
\text { /1970 } \\
(-4.46)\end{array}$ & $\begin{array}{c}\text { Malaysia } \\
/ 1980 \\
(0.93)\end{array}$ & $\begin{array}{l}\text { PRC } \\
/ 2000 \\
(8.07)\end{array}$ & $\begin{array}{l}\text { Sri Lanka } \\
\text { /2000 } \\
(3.27)\end{array}$ & $\begin{array}{c}\text { Uruguay } \\
/ 1990 \\
(1.79)\end{array}$ & $\begin{array}{l}\text { Thailand } \\
\text { /2000 } \\
(3.39)\end{array}$ & $\begin{array}{c}\text { Norway } \\
/ 1970 \\
(3.85)\end{array}$ & $\begin{array}{c}\text { Netherlands } \\
/ 1970 \\
(2.84)\end{array}$ & $\begin{array}{l}\text { Poland } \\
\text { /2000 } \\
(4.11)\end{array}$ \\
\hline $\begin{array}{c}\text { Malaysia } \\
/ 1970 \\
(7.6)\end{array}$ & $\begin{array}{c}\text { Turkey } \\
/ 1970 \\
(1.48)\end{array}$ & $\begin{array}{c}\text { Mexico } \\
/ 1980 \\
(-1,55)\end{array}$ & $\begin{array}{c}\text { Bolivia } \\
\text { /2000 } \\
(3.50)\end{array}$ & $\begin{array}{c}\text { Korea, Rep. } \\
\quad / 1980 \\
(9.42)\end{array}$ & $\begin{array}{c}\text { Indonesia } \\
\text { /2000 } \\
(2.48)\end{array}$ & $\begin{array}{c}\text { Portugal } \\
/ 1970 \\
(2.76)\end{array}$ & $\begin{array}{l}\text { Japan } \\
/ 1970 \\
(4.08)\end{array}$ & $\begin{array}{c}\text { Malaysia } \\
/ 1990 \\
(4.67)\end{array}$ & $\begin{array}{c}\text { Malaysia } \\
/ 2000 \\
(2.80)\end{array}$ & $\begin{array}{c}\text { Lithuania } \\
\text { /2000 } \\
(4.76)\end{array}$ \\
\hline
\end{tabular}


